\title{
Youth in Pakistan: Priorities, realities and policy responses
}

\author{
Zeba Sathar \\ Population Council \\ Iram Kamran \\ Population Council \\ Maqsood Sadiq \\ Population Council \\ Sabahat Hussain \\ Population Council
}

Follow this and additional works at: https://knowledgecommons.popcouncil.org/departments_sbsr-pgy

Part of the Demography, Population, and Ecology Commons, Family, Life Course, and Society Commons, and the International Public Health Commons How does access to this work benefit you? Let us know!

\section{Recommended Citation}

Sathar, Zeba, Iram Kamran, Maqsood Sadiq, and Sabahat Hussain. 2016. "Youth in Pakistan: Priorities, realities and policy responses." Islamabad: Population Council. 
the David Lucile Packard FOUNDATION
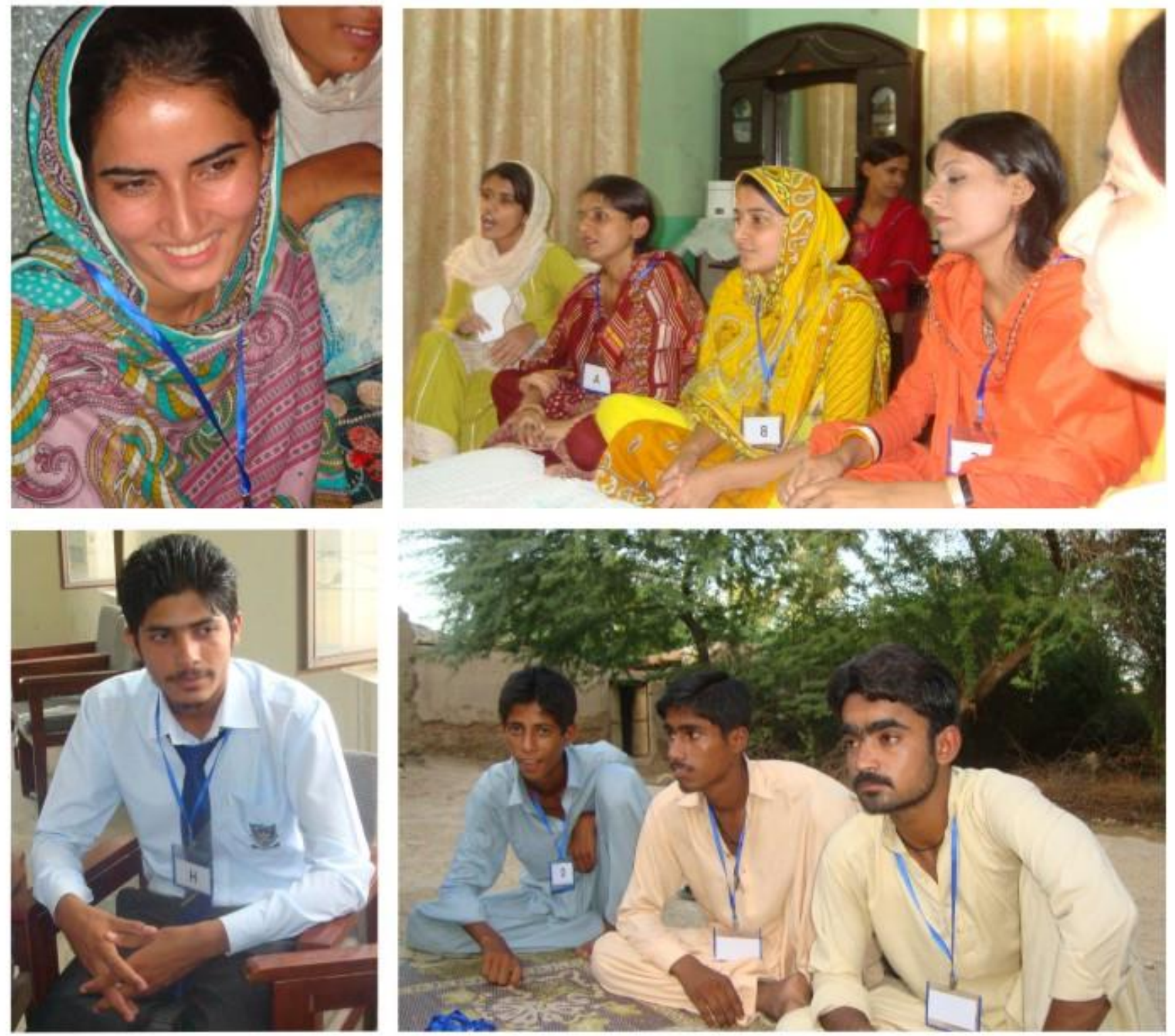

Youth in Pakistan:

Priorities, Realities and Policy Responses

August, 2016 



\section{POPULATION} COUNCIL

Ideas. Evidence. Impact. the David

Lucile PaCkard FOUNDATION

\section{Youth in Pakistan:}

\section{Priorities, Realities and Policy Responses}

Authors:

Zeba A. Sathar

Iram Kamran

Maqsood Sadiq

Sabahat Hussain
Contributors:

Ali Muhammad Mir

Zeba Tasneem

Tahira Parveen

Rehan Niazi 


\section{POPUlation COUNCIL \\ Ideas. Evidence. Impact.}

The Population Council confronts critical health and development issues-from stopping the spread of HIV to improving reproductive health and ensuring that young people lead full and productive lives. Through biomedical, social science, and public health research in 50 countries, we work with our partners to deliver solutions that lead to more effective policies, programs, and technologies that improve lives.

(c) 2016 The Population Council, Inc.

For inquiries, please contact:

Population Council

Add: $\quad 7$, Street 62, F-6/3, Islamabad, 44000, Pakistan

Tel: $\quad 92518445566$

Fax: 92512821401

Email: info.pakistan@popcouncil.org

Web: http://www.popcouncil.org

Layout and design: Ali Ammad

Published: August 2016 


\section{Contents}

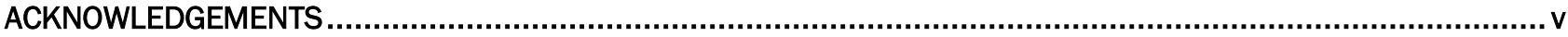

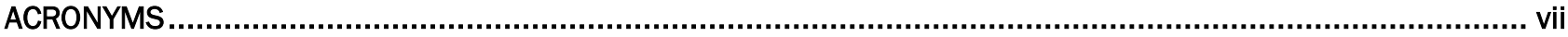

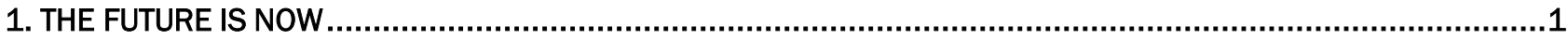

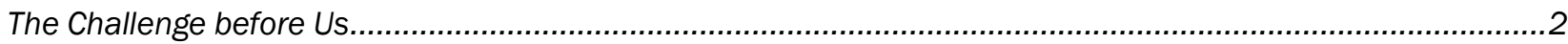

Disparities among Youth and the Need for a Segmented Approach ...............................................................

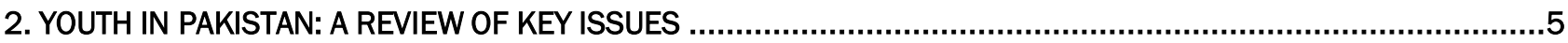

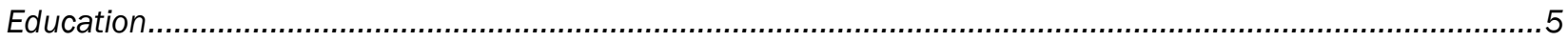

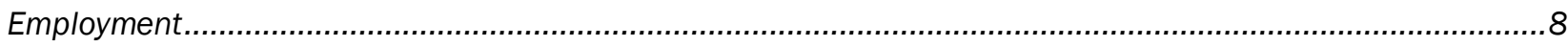

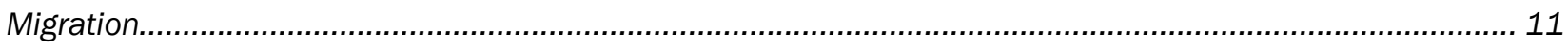

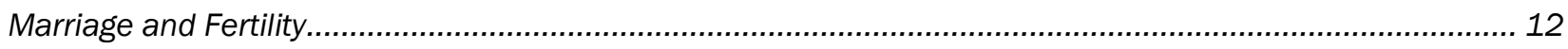

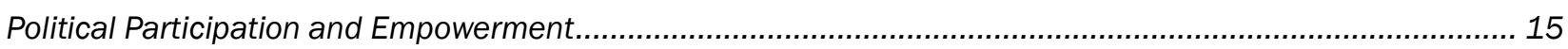

3. DIFFERENT KINDS OF YOUNG PEOPLE AND THEIR NEEDS .............................................................. 17

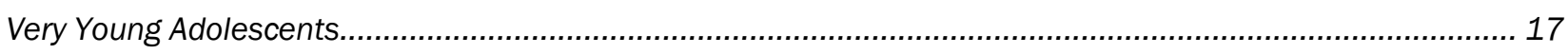

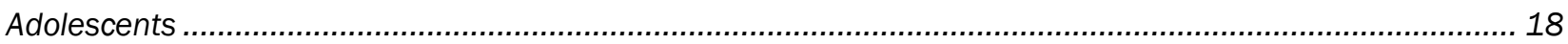

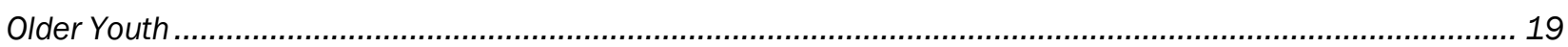

Life Trajectory Differences among Youth by Gender and Residence ........................................................... 20

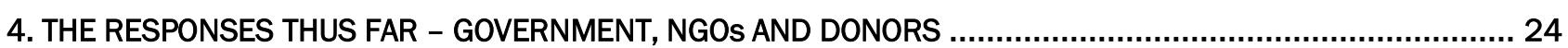

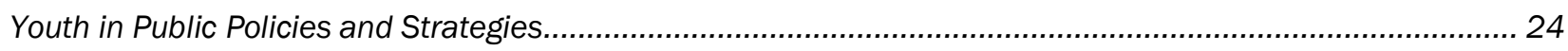

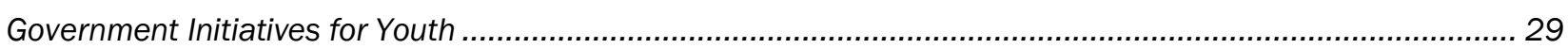

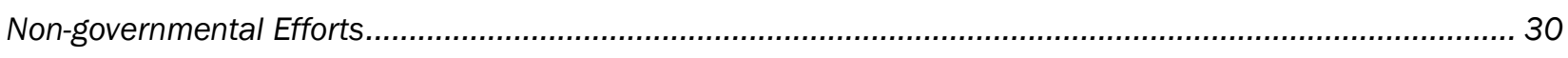

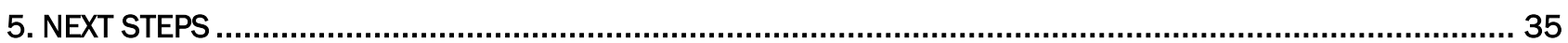

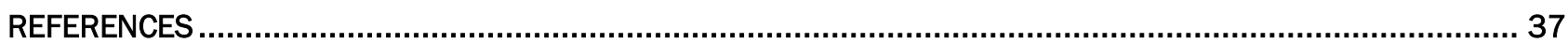





\section{ACKNOWLEDGEMENTS}

We would like to express our gratitude to The David and Lucile Packard Foundation for the funding and support that made it possible to produce this important paper. We extend our deep thanks to Dr. Gul Rashida, Population Council, who led our path in analyzing policies, programs and interventions. We also especially thank Ms. Seemin Ashfaq and Mr. Khan Muhammad at Population Council, as well as Ms. Sadia Atta Mehmood, United Nations Population Fund (UNFPA) for their help in accessing documents and liaising with departments and organizations.

The paper could have not been finalized without constructive input and tireless editing by Ms. Kiren Khan, who made this document presentable; we want to express our special thanks to her. We also want to greatly acknowledge Mr. Ali Ammad for providing his expertise in layout and formatting. Finally, we extend our deep gratitude and appreciation to all departments and organizations working with youth for their support in providing relevant data and documents. 



\section{ACRONYMS}

ADB

AJK

ASPRs

AUSAID

AYP

BISP

BMC

CAMP

DFATD

DFID

Eds

EMSDUUY

EU

FATA

GB

GCC

GDP

GIZ

HIV/AIDs

ICT

ICT

ILEAD

ILO

INSPYRE

IUCN

JICA

KP

LHW
Asian Development Bank

Azad Jammu and Kashmir

Age-specific Participation Rates

Australian Agency for International Development

Adolescent and Youth in Pakistan

Benazir Income Support Programme

Biomed Central

Community Appraisal and Motivation Programme Society

Global Affairs Canada/Department of Foreign Affairs, Trade and Development

Department for International Development, United Kingdom

Editors

Establishment of Mobile Skill Development Unit for Underprivileged Youth

European Union

Federally Administered Tribal Areas

Gilgit-Baltistan

Gulf Cooperation Council

Gross Domestic Product

Gesellschaft für Internationale Zusammenarbeit (German Society for International Cooperation)

Human Immunodeficiency Virus/Acquired Immune Deficiency Syndrome

Islamabad Capital Territory

Information and Communication Technology

Inspiring Leadership, Empowerment and Development

International Labour Organization

Inspiring Pakistani Youth to Reach Excellence Through Counseling and Training

International Union for Conservation of Nature

Japan International Cooperation Agency

Khyber Pakhtunkhwa

Lady Health Worker 
MSDS

NADRA

NAVTTC

NDMA

NGOs

OCHA

PAIMAN

PDHS

PEEF

PSLMS

PYTES

RSPN

SDC

SDGs

SDPI

SES

STIS

SWD

TDEA

TEVTA

UAE

UN

UNDP

UNICEF

UNODC

USAID

VYA

YDI

YES
Minimum Service Delivery Standards

National Database and Registration Authority

National Vocational and Technical Training Commission

National Disaster Management Authority

Non-government organizations

United Nations Office for the Coordination of Humanitarian Affairs

Pakistan Initiative for Mother and Newborns

Pakistan Demographic and Health Survey

Punjab Education Endowment Funds

Pakistan Social and Living Standards Measurement Survey

Free Provincial Youth Technical Education Scheme

Rural Support Programmes Network

Swiss Agency for Development and Cooperation

Sustainable Development Goals

Sustainable Development Policy Institute

Socio-economic Status

Sexually Transmitted Infections

Social Welfare Department

Trust for Democratic Education and Accountability

Technical Education and Vocational Training Authority

United Arab Emirates

United Nations

United Nations Development Program

United Nations Children's Fund

United Nations Office on Drugs and Crime

United States Agency for International Development

Very Young Adolescents

Youth Development Index

Youth Empowering Spaces 


\section{THE FUTURE IS NOW}

Youth is a period of multiple transitions, physical, cognitive, sexual, emotional, and social. Adolescence, in particular, represents a time when "lifelong health behaviors are formed, when pathways of opportunity or risk emerge, and when the future life course begins to take shape" (McCarthy, Brady, \& Hallman, 2016). The opportunities young people have been given in their growing years and the circumstances surrounding them as they transition to adult roles can permanently shape the future architecture of their lives. Youth is therefore a pivotal stage during which the right policies and interventions in the health, social, educational and economic sectors can protect young people against risks, and turn the trajectories of their lives towards a safe and productive path of growth.

According to the latest projections of the Population Council, the population of Pakistan stood at 191 million in 2015. Young people aged 10 to 24 years comprise 32 percent of the total population. Of these about 61 million young people, 32 million are male and 29 million are female. Broken down by age, very young adolescents (VYA), aged 10-14 years, comprise 11 percent of the total population, as do older adolescents (15-19 years), while young men and women aged 20-24 years comprise about 10 percent of Pakistan's population (Figure 1.1).

\section{Figure 1.1: Breakdown of Youth Population by Sex and Age - Pakistan 2015}

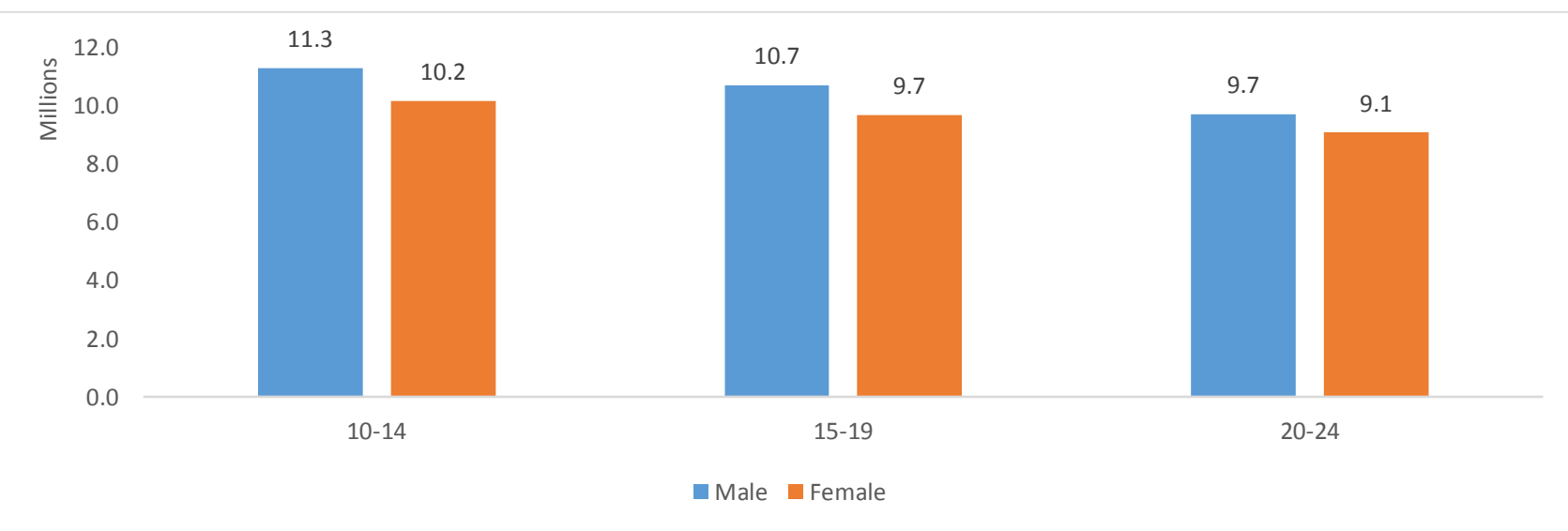

Source: Population Council Revised Population Projections 2015

Recent years have seen a growing recognition of the need to focus on youth in development. The large cohort of young people is seen as the center of the prospects of capturing the demographic dividend in Pakistan (Kugelman and Hathaway, 2011 and Sathar, Royan and Bongaarts, 2013). More recently Pakistan's adoption of the 17 Global Sustainable Development Goals (SDGs) reaffirms our commitment to investing in youth as a development strategy. Globally, young people's critical role as agents of change has been recognized as a crucial element of the sustainable development agenda. Of the 169 SDG targets, as many as 65 directly or indirectly refer to young people and 20 targets-pertaining to Goal 2 (hunger), Goal 4 (education), Goal 5 (gender equality), Goal 8 (decent work), Goal 10 (inequality), and Goal 13 (climate change)-specifically apply to youth. Moreover, Goals 16 (peaceful, just and inclusive societies) and 17 (partnerships and implementation) also imply the engagement and participation of young people in development and accountability (UNDP, 2016).

"Pakistan's youth bulge can drive innovation and entrepreneurship. The Government of Pakistan is committed to addressing this situation through major investment in youth." Pakistan Vision 2025 
Most importantly, the Government of Pakistan was already moving in this direction in 2015: Pakistan Vision 2025 aims to "channelize and streamline the energies of Pakistan's large youth population and realize their immense economic potential," noting in particular the youth-based "strong digital potential to develop a knowledge-based industry fostering innovation and entrepreneurship." However, while Vision 2025 focuses primarily on youth's economic promise-and this is consistent with the national resolve to capitalize on Pakistan's demographic dividend-Pakistan's 61 million young citizens can also be key enablers of wider development outcomes.

Youth development is critical for young people to realize their capabilities to pursue gainful and decent employment, education opportunities, health and wellbeing, as well as civic and political empowerment (The Commonwealth, 2013). When we support healthy transitions to adulthood-by meeting the unique developmental needs of youth, by safeguarding their rights, and by protecting them against being prematurely thrust into adult roles-we are investing when it counts. When we engage youth meaningfully as partners in development, we are laying the foundation of an inclusive and empowered society.

"The future of humanity and of our planet lies in our hands. It lies also in the hands of today's younger generation who will pass the torch to future generations." 2030 Agenda, paragraph 53

\section{The Challenge before Us}

Among the 54 Commonwealth countries, Pakistan currently ranks 22nd against the Commonwealth Youth Development Index (YDI), with a score of 0.63 (Commonwealth, 2013). The YDI is a composite index based on 15 indicators under five key domains of education, health and wellbeing, employment, civic participation, and political participation. Pakistan has one of the lowest youth unemployment rates, but below-average metrics related to other aspects of youth unemployment: for example, on average, most people have only spent five years in school. The fact that low youth unemployment is coupled with low educational outcomes raises concerns about the restricted pathways being taken towards adulthood (Lloyd and Grant, 2005).

Lloyd and Grant (2005) examined transitions to adulthood in Pakistan with a focus on gender differences. The results of the analysis confirm the fundamental importance of schooling to transitions to adulthood. Those without any schooling assume the work burdens of adults prematurely and are deprived of the opportunity to learn in an institutional setting outside the family. Definitely, youth who do attend school have the benefit of a longer transition to adulthood.

For both male and female youth, there appears to be a large lag in years between the assumption of adult work roles, whether in the domestic setting or in the labor market, and the assumption of adult family roles as marked by the timing of first marriage. In the case of young women, delay in the timing of first marriage has increased in recent years, accompanied by a rise in the percentage working for pay during the later adolescent years; a similar trend is not apparent for young men.

In the past few years, there is a growing sense of the urgency to respond to the challenges of youth employment. The challenges are multi-faceted: among other issues, the transition from school to the labor market is not smooth; the youth unemployment rate is higher than the adult unemployment rate; many young people work in the informal sector as unpaid family workers, own-account, or casual wage workers; and female youth are in worse position than their male counterparts on various employment dimensions. While many problems in this sphere apply to adults as well, some challenges are youth-specific, such as the insufficient returns at initial job entry for better-educated youth. For these challenges, more youth-specific interventions are needed (Hou, 2010). 
The British Council's (2009) next generation survey found a quarter of respondents (18-29 year olds) to be illiterate. Half believed they did not have skills for the modern labor market. Even those with good qualifications were struggling to find decent employment, and complained of discrimination and corruption. On the other hand Pakistan's rural youth are marginalized from mainstream development, massively disadvantaged, and face huge obstacles in all aspects of their lives. The British Council study shows that youth in general are frustrated with the government and thoroughly disenchanted by mainstream politics (British Council, 2013).

Clearly, all these countervailing trends point to the importance of investing in the next generation and doing more now to prevent young lives from going off-course. This will be impossible unless we have in place clear policies that include and respond to the needs of youth, and follow these up with consistent socio-political will and adequate investments. The urgency is heightened by the huge economic stakes: Pakistan is at a stage in its demographic transition where declining fertility has stalled the increase in dependents while the workforce remains large, reflecting earlier high fertility. ${ }^{1}$ The resulting temporary drop in the dependency ratio offers a time-bound opportunity to accelerate economic growth. To reap this demographic dividend, however, prompt action must be taken to ensure that the swelling cohorts of working-age people are productively employed (Bloom, 2013).

"Pakistan will have one of the youngest workforces in the world by 2025. The Vision aims to cash in on this demographic dividend by educating and building the skills of its population." Pakistan Vision 2025

\section{Disparitles among Youth and the Need for a Segmented Approach}

In developing strategies for youth development and mechanisms for their participation, a fundamental reality that is often ignored is that all youth are not born into households with equal opportunities. Faizunisa and Ikram (2004) developed a Youth Development Index for Pakistan using four sets of indicators concerning educational attainment, employment, recreation, and health seeking behavior. The analysis revealed stark differences among young people across provinces and urban/rural residence. Gender differences were acute, with girls significantly less likely than boys to get an education or be part of the paid labor force, especially in rural areas.

Similar disparities had been observed and included in the discourse around youth policy a decade ago by the Population Council, when it undertook the "Adolescent and Youth in Pakistan (AYP)" survey in 2001-2002 to fill a gap of information about young people in Pakistan. In this effort, which comprised the largest nationally representative survey of young Pakistanis, information was collected from young people (aged 15-24) as well as key informants in each of the 254 surveyed communities. The most important findings of the survey related to the asymmetry in the experiences of young women and men in growing up. In most instances, gender disparities were further exacerbated by low socio-economic status (SES) and rural residence: girls from the poorest families in rural areas were most disadvantaged in every aspect.

Subsequent research largely reinforces these findings. Among older adolescents (15-19 years) who ever attended school, the gap between boys and girls in the richest group is small relative to that in the poorest group in both urban and rural areas. Availability of sufficient resources in richer households does reduce discrimination-and the gender gap in enrollment widens steadily from the highest to the lowest economic group. Girls' enrollment is highest in Punjab, but the gender gap among the poorest rural adolescents is also highest there, exceeding 50 percentage

1. With its high fertility, the young population will double by 2025 . The labor force has risen faster (3.7 percent a year) than the regional average (3.1 percent), a result of a larger working-age share of the population and a higher labor force participation (especially by women). The youth workforce has grown even faster, at 4.3 percent a year, well above the regional average of 2.7 percent and is expected to continue at that rate for at least 10 years (World Bank, 2013). 
points. Poor girls living in rural areas thus suffer a triple disadvantage with poverty and rural location compounding the gender-based disadvantage they share with better-off urban peers (Lloyd, Mete, \& Grant, 2007).

While there has been some significant improvement in women's inclusion in politics, education and employment, young women in Pakistan continue to face very high levels of exclusion. Women are much less educated than men and many are confined within their homes. They are less politically engaged and fewer than half of them currently expect to vote, even though nearly three quarters are registered to do so. Some may be registered without knowing due to Pakistan's new computerized electoral roll (British Council, 2013).

It is also necessary to be mindful of age-related difference in needs. Very young adolescents (10-14 years), older adolescents (15-19 years), and young adults (20-24 years) have quite different health, educational, and social needs. The nature of needs is further affected by where they stand in the transition to adulthood, specifically, whether they have had time to "grow up" or have been prematurely pushed into the world of adult responsibilities. These different age cohorts will require different interventions to cater to their specific needs. Young people's needs must be assessed based on their age, their gender, the economic status of the household, and the profile of the community where they live (Sathar, et al., 2003), and services and opportunities provided to them accordingly.

In the following pages, we outline some of the key issues facing youth in Pakistan, in the main spheres marking their transition to adult roles. We also present the results of an age-based segmentation analysis capturing where youth in Pakistan stand in terms of school enrollment, work force participation, and marriage, with a view to identifying the broad developmental priorities for each cohort. This is followed by a brief look at current policies and strategies, and the interventions of government and non-governmental stakeholders for youth development. The paper concludes with remarks about the adequacy of current arrangements for affording our youth healthy transitions to adulthood, and preliminary suggestions for future research and action. 


\section{YOUTH IN PAKISTAN: A REVIEW OF KEY ISSUES}

Between the ages of 10 and 24, young people adapt to a rapidly growing series of roles as students, workers, migrants, spouses, parents, and citizens. In this review, we draw on recent research to outline the situation of youth in Pakistan in the context of these important areas of transition. While the list of issues and discussion are far from exhaustive, this section conveys some of the key themes and the complexity of issues surrounding youth, and incorporates an analysis of population data to indicate scale and trends.

\section{Education}

The education sector is perhaps the least neglected area of young people's development in Pakistan. By any yardstick, the most important and essential asset that youth can hope and expect to acquire is a basic primary and secondary education. This is where the gap in the lives of youth begins to appear in terms of huge deficits for those children who never enter school, and, to a slightly lesser extent, for those who drop out early and do not continue to complete what in today's world is an essential minimum standard of education.

It is beyond the scope of this preliminary paper to adequately encapsulate the vast volume of thought and action on education in Pakistan. Therefore, while affirming the unquestionable imperative of greater understanding and effort for universal access to quality education, we limit our discussion, for the present, to tracing how many young people take the first step into school and how far they are able to complete the expected transition to graduation.

We know that about $86 \%$ of boys and $75 \%$ of girls aged $10-14$ are ever enrolled in schools (Table 2.1). Ever enrollment is higher for this group than among young people aged 20-24, reflecting education improvements over time. The table below also shows differences by urban/rural residence, province and, most of all, by wealth quintile. Only $64 \%$ of boys and $40 \%$ of girls aged $10-14$ years ever enrolled in school if they belonged to the poorest of households. Girls in Balochistan, Sindh and Khyber Pakhtunkhwa (KP) lag behind boys in the same provinces.

Table 2.1: Percentage of Youth Ever Enrolled in a School/Educational Institution, by Sex and Age Group - Pakistan 2014-15

\begin{tabular}{lrr|rr|rr}
\hline Background & \multicolumn{2}{c|}{$\mathbf{1 0 - 1 4}$} & \multicolumn{2}{c|}{ 15-19 } & \multicolumn{2}{c}{ 20-24 } \\
\cline { 2 - 7 } Characteristics & Male & Female & \multicolumn{1}{c}{ Male } & Female & Male & Female \\
\hline Pakistan & 86.1 & 75.4 & 82.0 & 69.5 & 79.4 & 61.9 \\
Rural & 83.5 & 67.1 & 78.0 & 60.1 & 74.0 & 49.5 \\
Urban & 91.8 & 91.4 & 89.1 & 86.2 & 87.3 & 82.3 \\
\hline Province & & & & & & \\
KP & 93.3 & 69.2 & 88.1 & 56.2 & 83.9 & 42.8 \\
Punjab & 88.3 & 82.8 & 84.4 & 76.3 & 81.0 & 69.3 \\
Sindh & 77.9 & 66.6 & 76.1 & 64.0 & 76.4 & 59.4 \\
Balochistan & 80.4 & 53.7 & 69.4 & 43.7 & 63.7 & 28.0 \\
\hline Wealth Quintile & & & & & & \\
Lowest & 64.2 & 39.7 & 53.2 & 27.4 & 49.0 & 16.5 \\
Second & 84.2 & 69.2 & 75.2 & 56.8 & 67.7 & 40.0 \\
Middle & 91.9 & 84.9 & 86.0 & 76.3 & 82.0 & 64.3 \\
Fourth & 96.0 & 92.3 & 93.6 & 85.4 & 89.7 & 80.7 \\
Highest & 98.6 & 95.7 & 96.7 & 92.5 & 96.0 & 89.0 \\
\hline
\end{tabular}

Source: Pakistan Social and Living Standards Measurement Survey (PSLMS) 2014-15 
The extent to which children who are ever enrolled in schools are able to complete the journey to graduation can be deduced from Table 2.2, which sums up educational attainment among ever-enrolled children and youth, and from Figure 2.1, which shows clearly the proportions of youth who have left school.

In Table 2.2, a comparison across age groups for the earlier stages (below primary and primary) indicates that a higher proportion are reaching the first milestones. Similarly, young people aged 15-19 are faring far better than the older cohort (20-24) in terms of completing the middle level. Unexpectedly, a higher proportion of older females aged 20-24 proceed to intermediate and graduate studies (35.4\%) than male students (27\%).

Table 2.2: Percentage Distribution of Youth by Educational Levels Attained among Those Who Ever Attended School, by Sex and Age Group - Pakistan 2014-15

\begin{tabular}{lrrr|rrr}
\hline & \multicolumn{4}{c|}{ Male } & \multicolumn{3}{c}{ Female } \\
\cline { 2 - 7 } Education level attained & $\mathbf{1 0 - 1 4}$ & $\mathbf{1 5 - 1 9}$ & $\mathbf{2 0 - 2 4}$ & $\mathbf{1 0 - 1 4}$ & $\mathbf{1 5 - 1 9}$ & $\mathbf{2 0 - 2 4}$ \\
\hline Below Primary & 50.6 & 8.2 & 7.0 & 47.2 & 7.6 & 4.3 \\
Primary & 42.2 & 24.4 & 20.0 & 43.3 & 26.5 & 21.9 \\
Middle (8th grade) & 7.0 & 36.5 & 19.0 & 9.1 & 31.5 & 14.1 \\
Matriculation & 0.2 & 24.0 & 27.0 & 0.3 & 24.3 & 24.3 \\
Intermediate & 0.0 & 6.3 & 17.3 & 0.0 & 8.8 & 20.1 \\
Graduation & 0.0 & 0.5 & 9.8 & 0.0 & 1.3 & 15.3 \\
Total & $\mathbf{1 0 0}$ & $\mathbf{1 0 0}$ & $\mathbf{1 0 0}$ & $\mathbf{1 0 0}$ & $\mathbf{1 0 0}$ & $\mathbf{1 0 0}$ \\
\hline
\end{tabular}

Source: PSLMS 2014-15

Despite these positive trends, however, the fact remains that only a small fraction of young people acquire more than a secondary education. Among older youth (ages 20-24), who currently number roughly 19 million, only about $13 \%$ are currently enrolled in any educational institution, $26 \%$ have completed secondary school, and a mere $19 \%$ went on to get a higher secondary (intermediate) education.

Figure 2.1 shows the differences by gender in completing primary, dropping out during primary and completing at least a secondary education for 10-19 year olds. It shows that while over half of all adolescents have completed at least primary education, barely 11 percent complete secondary education and beyond. A higher proportion of boys (27\%) dropped out during primary school compared to $22 \%$ of girls. These data indicate the need for strong interventions to improve retention of students in school, alongside enrollment. 
Figure 2.1: Distribution of adolescents (aged 10-19) who completed primary and secondary education, and those that dropped out during primary stage, by sex

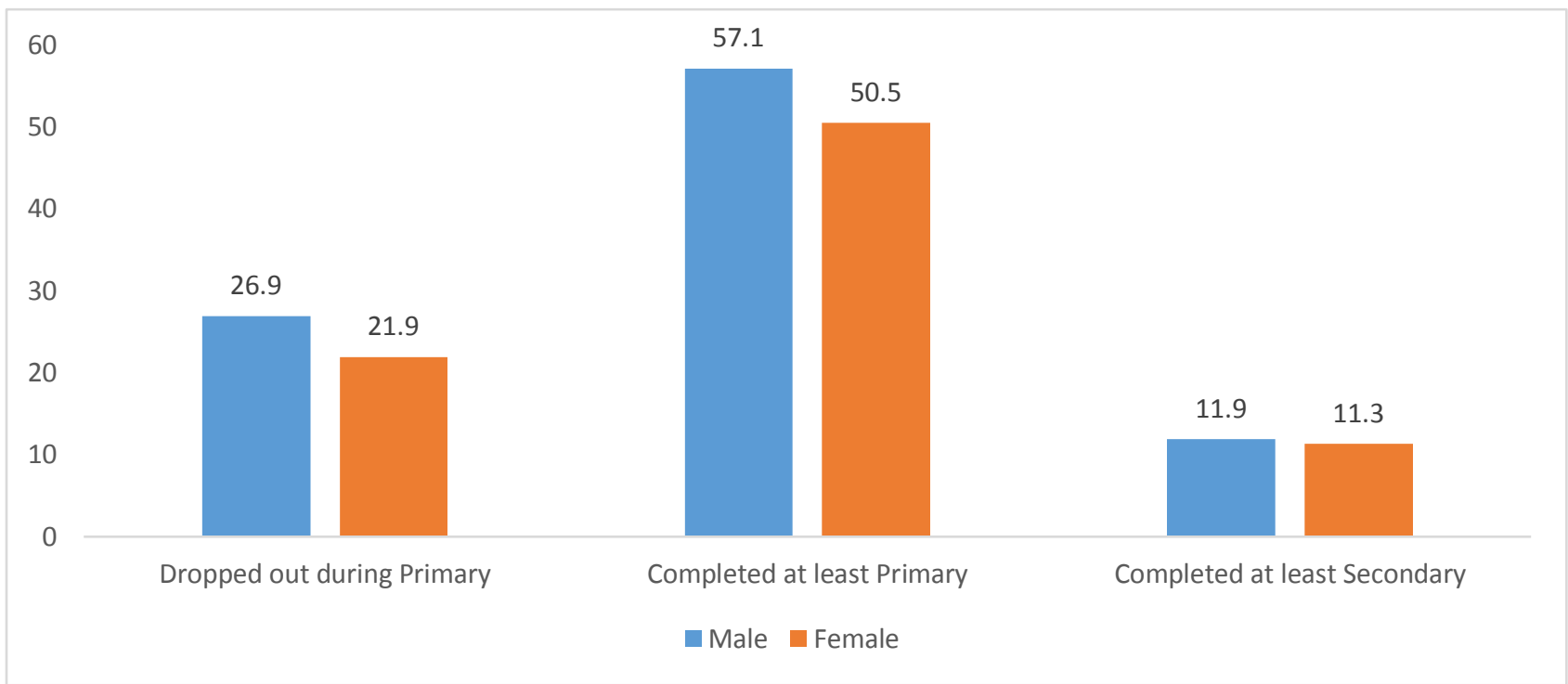

Source: PSLM 2014-15

In understanding why young people leave school, gender differences in reasons for dropping out are informative (Table 2.3). For boys "child not willing" features as a major reason, followed by "education is expensive." On the other hand among girls the reasons have more to do with distance from school, the need to help with work at home, and parents' refusal to send their child to school.

Table 2.3: Most Frequently Cited Reasons for Leaving School/Educational Institution, \% of Population - Pakistan 2014-15

\begin{tabular}{|c|c|c|c|c|c|c|}
\hline \multirow[b]{2}{*}{ Main Reason } & \multicolumn{2}{|c|}{$10-14$} & \multicolumn{2}{|c|}{$15-19$} & \multicolumn{2}{|c|}{$20-24$} \\
\hline & Male & Female & Male & Female & Male & Female \\
\hline Child not willing & 49 & 28 & 47 & 25 & 36 & 21 \\
\hline Education is expensive & 13 & 12 & 14 & 14 & 13 & 12 \\
\hline Too far flung & 4 & 10 & 4 & 10 & 2 & 7 \\
\hline Had to work at home & 1 & 12 & 1 & 13 & 1 & 15 \\
\hline Had to help with work & 6 & 2 & 7 & 2 & 8 & 2 \\
\hline Parents do not allow & 2 & 20 & 1 & 19 & 1 & 17 \\
\hline Marriage & 0 & 0 & 0 & 3 & 0 & 11 \\
\hline Due to job or work & 6 & 0 & 16 & 1 & 26 & 2 \\
\hline
\end{tabular}

Source: PSLMS 2014-15

Despite improvements, a large proportion of youth are still never enrolled in school, and among those who are, huge numbers are dropping out at each level till graduation. The implications in terms of young people's readiness for life challenges are staggering, the more so when we consider the rushed transitions that many youth who drop out have experienced or will make into jobs, marriages, and parenthood. More details about the schooling status of youth are presented later in this paper, in combination with data about marital and employment status. Aspects related to employment are also touched upon in the following section. 


\section{Employment}

According to the Labor Force Survey 2014-15, the labor force participation rate among youth (ages $10-24$ ) is $41.3 \%$ among males and $16.4 \%$ females. The unemployment rate is $9.8 \%$ among male youth and $12.3 \%$ among female youth. Table 2.4 presents the current scenario of labor force participation and unemployment among youth by age, residence, and gender.

Table 2.4: Labor Force Participation and Unemployment among Youth by Age, Sex and Residence - Pakistan 2014-15

\begin{tabular}{lrrr|rrr}
\hline & \multicolumn{3}{c}{ Male } & \multicolumn{3}{c}{ Female } \\
\cline { 2 - 7 } Rate and region & $\mathbf{1 0 - 1 4}$ & $\mathbf{1 5 - 1 9}$ & $\mathbf{2 0 - 2 4}$ & $\mathbf{1 0 - 1 4}$ & $\mathbf{1 5 - 1 9}$ & $\mathbf{2 0 - 2 4}$ \\
\hline Labor Force Participation Rate & & & & & & \\
Rural & 13.8 & 53.6 & 86.6 & 11.2 & 24.1 & 31.7 \\
Urban & 6.0 & 37.0 & 76.0 & 1.3 & 7.7 & 15.3 \\
Overall & $\mathbf{1 1 . 2}$ & $\mathbf{4 7 . 5}$ & $\mathbf{8 2 . 3}$ & $\mathbf{7 . 7}$ & $\mathbf{1 8 . 0}$ & $\mathbf{2 5 . 7}$ \\
\hline Unemployment Rate & & & & & \\
Rural & 10.0 & 8.4 & 8.3 & 5.0 & 7.9 & 12.2 \\
Urban & 22.2 & 14.2 & 10.6 & 21.8 & 23.4 & 31.4 \\
Overall & $\mathbf{1 2 . 2}$ & $\mathbf{1 0 . 0}$ & $\mathbf{9 . 2}$ & $\mathbf{6 . 0}$ & $\mathbf{1 0 . 4}$ & $\mathbf{1 6 . 4}$ \\
\hline
\end{tabular}

Source: Labor Force Survey 2014-15

The age-specific participation rates (ASPRs) of early teens currently show a declining trend: in 2005-06 (data not shown), the labor force participation rate for young males aged 10-14 was 20.7\%; this dropped in 2014-15 to $11.2 \%$, for females' rates declined from $9.2 \%$ to $7.7 \%$ which is a positive sign. Also encouraging is the ASPR for female youth aged 20-24, increased by 5 percentage points from $20.7 \%$ to $25.7 \%$ over the same period. For the male youth age group of $20-24$, the rate has curved down from $87.6 \%$ to $82.3 \%$. (Figure 2.2).

Figure 2.2: Rates of Labor Force Participation and Unemployment among Youth by Sex and Age Pakistan 2014-15

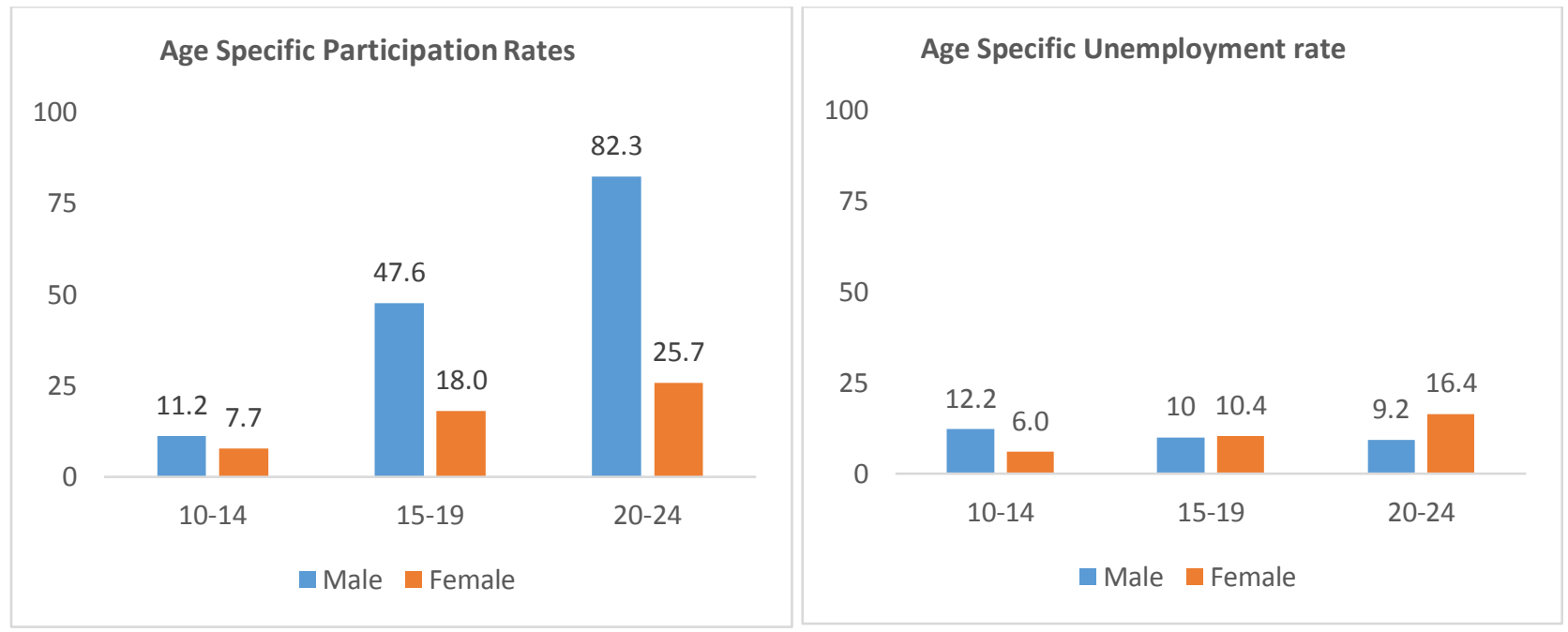

Source: Labor Force Survey 2014-15 
Earlier, in 2005/2006, according to the Pakistan Employment Trends for Youth report, employment growth had outpaced population growth among young people in Pakistan. However, youth employment decreased by 0.1 million in the year (2006/2007), resulting in a reduction of the employment-to-population rate from $42.0 \%$ in $2005 / 2006$ to $40.9 \%$ in $2006 / 2007$. Youth labor force participation rates, after several years of increase, also decreased by 1.7 percentage points. Importantly, the large gender gaps in the youth labor market were observed to have narrowed since 1999/2000, though they remained significant (Government of Pakistan, 2008). Age-specific unemployment rates are highest (11\%) among youth aged $20-24$, specifically $9.2 \%$ among males (compared to a national average of $5 \%$ among males) and $16.4 \%$ for females (as against a national average of $9 \%$ among females).

Comparing the labor force participation and unemployment rates (Table 2.4), we find that the majority of girls and a significant portion of boys who wish to work are not gainfully employed. There are major differences in the labor market involvement of both sexes across rural and urban areas. Unemployment rates are higher among youth living in urban areas, while the primarily agrarian rural economy is either able to absorb most labor force entrants or forces them to migrate to urban areas in search of non-agricultural jobs. The higher unemployment rates among young females are attributed by Ahmad and Azim (2010) to mobility and other constraints in finding suitable employment, especially in urban areas.

With the impressive gains in education there are millions more educated youth than a decade ago. The investments in education are clearly linked to desire for better opportunities, locally and elsewhere, often spurring migration. Expectations in terms of both type of employment and remuneration have changed among both boys and girls. It is important to ask whether there is a link between employment and educational levels attained. Hou (2010) finds that the unemployment rate is much higher for better-educated youth. Hou's findings are supported by data in the Labor Force Survey 2014-15, which presents a clear pattern of rising unemployment with increasing education levels for both young males and females (Figure 2.4). The unemployment rate are highest for males with degrees at $34 \%$-in contrast to much lower levels for those with intermediate degrees or below. But this figure is no match for the staggeringly high levels of unemployment among females with an intermediate education (45\%) and with a degree (55\%). This shows greater likelihood of a lack of matching opportunities as a serious issue for girls who are striving for higher education and achieving it.

In terms of labor force participation, we find the highest rates among young males with the lowest educational attainment, with graduates participating at a slightly lower rate than those with primary education. Considerably lower proportions of male youth at intervening tiers of education are entering the work force although, at roughly $45 \%$, their involvement is far from insignificant (Figure 2.3). Labor force participation rates for young females shows a curvilinear relationship demonstrated by a U-shaped curve, with higher employment rates for the least educated followed by increasing rates for young females with a degree. Labor force participation rates for young females at other levels are practically negligible. 
Figure 2.3: Labor Force Participation Rates by Educational Attainment among Older Youth (aged 15-24) - Pakistan 2014-15

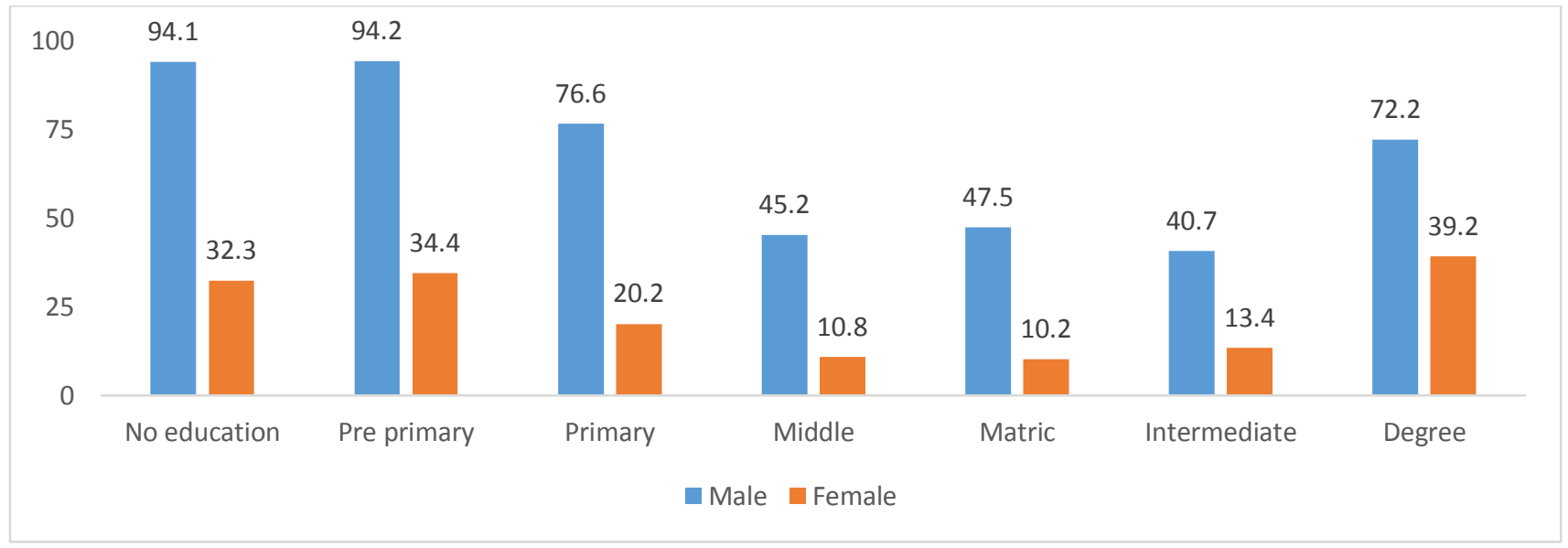

Source: Labor Force Survey 2014-15

Figure 2.4: Unemployment Rates by Educational Attainment among Older Youth (aged 15-24) - Pakistan 2014-15

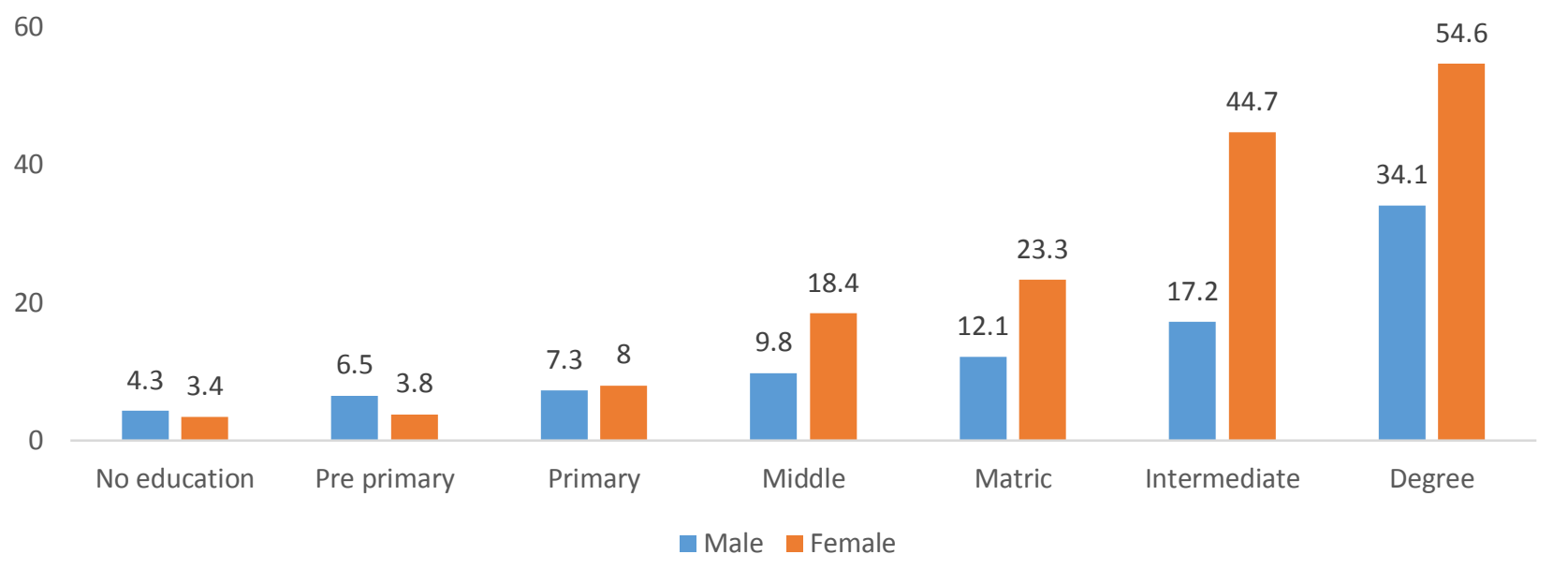

Source: Labor Force Survey 2014-15

Rates of returns to education remain respectable in Pakistan and thus educated youth tend to benefit from schooling in the long run (Mete and Rehan, 2013). Given the foregoing picture of school enrollment, unemployment, and labor force participation, Pakistan's youth employment challenge is clearly much broader than the problem of providing suitable opportunities to more educated youth. It must be acknowledged that while more educated youth are also more vocal than other young people, and often more visible to policymakers, the high unemployment rates they face are due partly to their higher reservation wages, rather than the absence of jobs.

Youth unemployment in Pakistan has been attributed to a lack of institutions to guide young students in selecting fields of study that match the requirements of the economy (Qayyum 2007). Structural unemployment along with the low incomes and below subsistence wages have also been held responsible for the perpetuation of the vicious circle of unemployment by Akhtar and Shahnaz (2006). The authors find that growth in private sector investment is 
more conducive than public sector investment to reducing youth unemployment. Moreover, growth in the services sector (as opposed to overall GDP) is more strongly linked with reduced female unemployment.

The youth unemployment issue is of course part of the larger unemployment issue. It is estimated that 3.1 million persons, of which 2.1 million will be young, are expected to enter the labor force every year over the next four decades (Hussain, 2013). According to another study, unemployment among youth only begins to decrease if the annual growth rate of GDP exceeds 4.25\% per annum (Akhtar and Shahnaz, 2006). But while growth in Pakistan's economy averaged 5\% per annum since 1974 and $6 \%$ during 2003-07, it has slowed down significantly in recent years, raising concerns about its ability to absorb the increasing number of unemployed youth (Planning Commission, 2010). If the real GDP growth rate remains at the post-crisis level (around 3\%), all things being equal, the unemployment rate by year of 2020 could be as high as 14 percent (Robalino, \& Cho, 2012).

According to experts, the national economy must grow by $6 \%$ a year to fully meet the needs of its growing working age population (Bongaarts, Sathar, and Mahmood, 2013, British Council 2009). With the country ranking 101 out of 133 nations on the Global Competitiveness Index, there is a need for urgent economic reforms that include, at their heart, the goal of providing the right skills and opportunities to the labor force, especially young women. In fact, a significant escalation in female labour force participation rates is a prerequisite for the economy to grow and for the demographic dividend to be achieved (Sathar and Royan, 2013).

\section{Migration}

Migration is a dominant part of transitions to adulthood in many societies and this is true for Pakistan as well. Younger persons are more likely to be on the move in search of educational, employment and other opportunities. In the case of females, most move homes after marriage. Whereas the Census is meant to provide a full picture of migration trends and volumes, the PDHS 2012-13 also gives a fairly good idea of migration levels in the households surveyed within the nationally representative sample.

Within the country, the major migrations happen among the cohorts aged 20-24 and 25-29. In the under-15 age group, migration is usually to accompany the family whereas with the older groups, young people are moving independently, either for marriage or related to self-search for better economic opportunities and schooling.

Table 2.5: Percentage of Households Reporting Youth In-migration - Pakistan 2012-13

\begin{tabular}{lccc}
\hline Age group & Male & Female & Both \\
\hline $10-14$ & 2.8 & 3.1 & 2.9 \\
$14-19$ & 2.6 & 3.7 & 3.1 \\
$20-24$ & 3.2 & 9.2 & 6.4 \\
$10-24$ (All Youth) & $\mathbf{2 . 9}$ & $\mathbf{5 . 2}$ & $\mathbf{4 . 0}$ \\
\hline
\end{tabular}

Source: Pakistan Demographic and Health Survey (PDHS) 2012-13

Among in-migrants in the young cohort most likely to migrate (ages 20-24), reasons for migration are worth noting: the majority of 20-24 year old girls moved for marriage and the majority of boys, for economic and educational opportunities, although 3\% of girls also moved for the same reason (Figure 2.5). In addition, as many as $4 \%$ of boys and $1 \%$ of girls migrated to escape war and violence. Fewer girls than boys "accompanied the family," implying that sex ratios of households with in-migrants are likely to be more masculine. 
Figure 2.5: Percent Distribution of In-migrants aged 20-24, by Common Reasons for Migration - Pakistan 2012-13

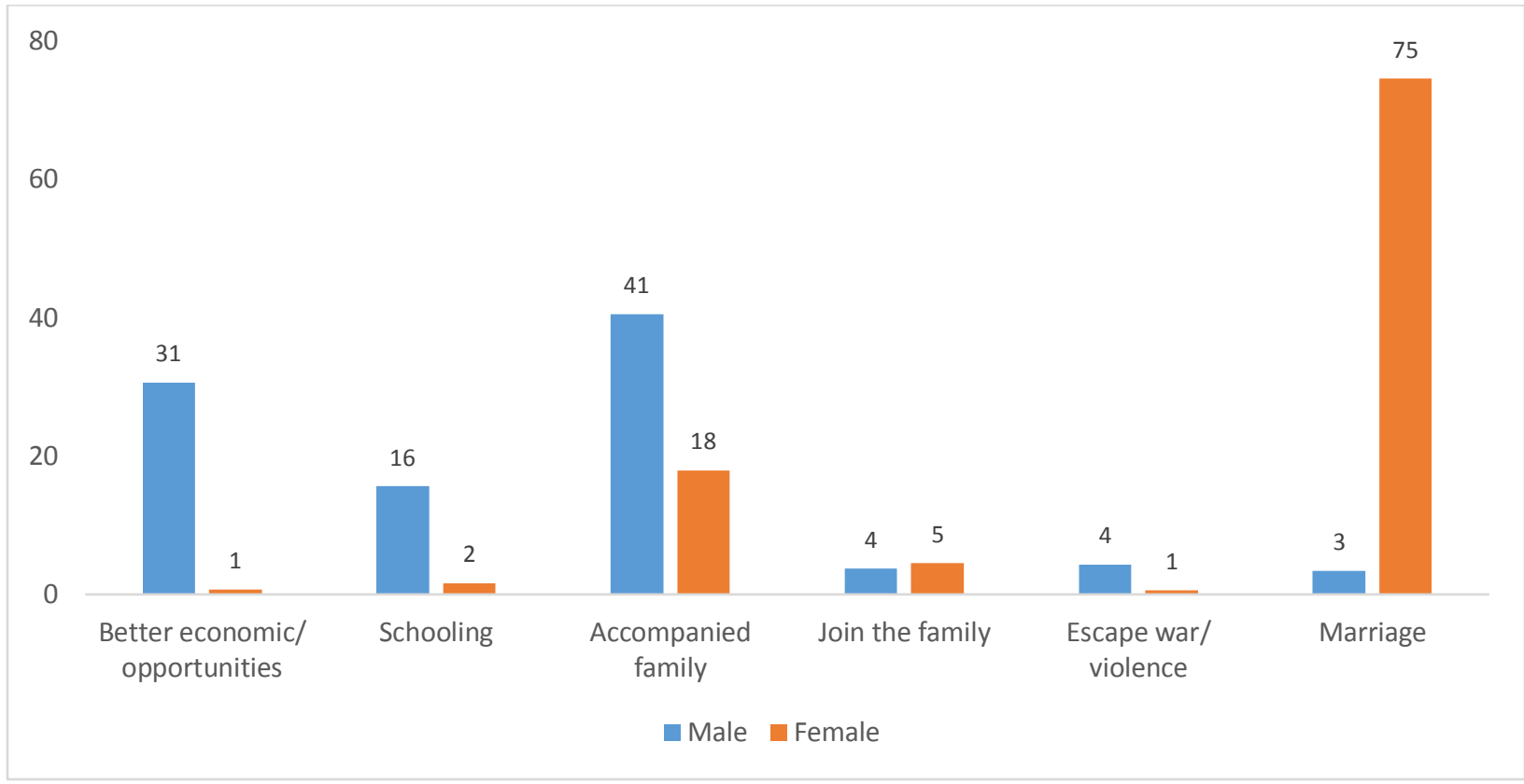

Source: PDHS 2012-13

While the above figures are a reflection of in-migrants, it is perhaps more important to point out that Pakistan is the second highest among South Asian nations in sending migrant workers abroad and describes itself as a country with pro-emigration policies. Between 1971 and 2013, more than 7 million Pakistanis-comprising more than 4\% of the country's population-have proceeded abroad for employment through the Bureau of Emigration. They currently reside in about 140 different countries around the world. About $96 \%$ of this manpower export has been to the Gulf Cooperation Council (GCC) countries: the key destination is Saudi Arabia, followed by the United Arab Emirates (UAE), Kuwait, Oman, Qatar and Bahrain (ILO, 2014). Emigration is largely male-dominated. They play a pivotal role in national development and growth through remittances.

About 50\% of out-migrants are aged 15-24. This makes it crucial for Pakistan to have in place a solid and clear policy for supporting overseas employment for Pakistani youth. This is necessary, not only to increase remittances, but also in the long-term interests of developing business and technological competencies within the Pakistani diaspora that can eventually be transferred back to the homeland to boost business, economic, social and technological development.

\section{Marrlage and Fertillty}

\section{Age at Marrlage}

One of the most prominent issues concerning young persons in Pakistan is early and childhood marriages. Gender issues underlie most of the harmful practices around early and forced marriages, and the deleterious effects of early marriages are definitely pitted more against girls. However, there are rare but significant incidences of traditional marriage practices that affect boys as well.

Fortunately, one of the major demographic changes in Pakistan is towards a higher age at marriage among boys and especially among girls. The median age at marriage for females has risen from about 17 to 19.5 between 1975 
and 2013. The singulate mean age at marriage has risen from 21.5 to 23.3 years for girls and 26.5 to 27.1 years for boys between 1991 and 2013. This measure also takes into account the rising proportions of boys and girls who do not marry. The shift in marriage ages is across the board, though there are some distinct patterns of age at marriage with a positive association with educational attainment as well as with residence in major cities and urban areas, and with the lowest ages at marriage prevailing in Sindh and Balochistan (Table 2.6).

Table 2.6: Median Age at First Marriage by Background Characteristics - Pakistan 2012-13

\begin{tabular}{lrr|r}
\hline Background Characteristic & & $\begin{array}{c}\text { Women } \\
\text { (aged 25-49) }\end{array}$ & $\begin{array}{c}\text { Men } \\
\text { (aged 30-49) }\end{array}$ \\
\hline Residence & Urban & 20.7 & 25.8 \\
& Rural & 18.8 & 24.1 \\
\hline Region & Punjab & 20.0 & 24.8 \\
& Sindh & 18.8 & 24.4 \\
& Khyber Pakhtunkhwa & 18.9 & 25.0 \\
Education & Balochistan & 18.5 & 24.1 \\
\hline & No education & 18.3 & 22.7 \\
& Primary & 19.3 & 24.4 \\
& Middle & 20.4 & 24.8 \\
\hline
\end{tabular}

Source: PDHS 2012-13

There appears to be a consensus of a preferred normative change in an ideal age of marriage of about 19-20 for girls and 23-24 for boys (Faizunissa and Haque, 2003). The rise in age at marriage implies higher physical and emotional maturity while entering an important marker of adulthood and parenthood, and it most importantly opens up a longer period for young persons to continue with education, skill building and development which can directly change life courses.

The increase in age at marriage is also likely to be accompanied by greater decision-making powers for younger persons in the choice of whom they marry. Previously young men but particularly women were expected to be obedient and to defer to their parents for decision-making around their marriages. The Adolescent and Youth Survey of Pakistan 2001-02 found that only $11.3 \%$ of boys and 3.7\% of girls had any say in choice of marriage partners. According to Hamid et al. (2011), having a say in the selection of a spouse is significantly associated with agreement with spouse over number of children to have, intention to use contraceptives, and the time between marriage and first contraceptive use. These relationships exist after controlling for education, socioeconomic status, mobility outside of house, and decision making in the home. Women who have decision-making freedom in their parental home carry this ability with them post-marriage in their new home and are better able to negotiate decisions about their fertility.

Legislation to enforce a higher legal age at marriage has recently been passed in the Sindh and Punjab provincial assemblies, through the 2014 Sindh Child Marriages Restraint Act 2013, and Punjab Marriage Restraint (Amendment) Act 2015 respectively; enforcement of these laws remains to be seen. 
More efforts need to be directed to pointing out the vulnerabilities of early and forced marriages which continue to prevail. Legislative changes and discourse in the media and across civil society will go a long way in tackling the remaining pockets of society where early marriages continue to take place.

\section{Fertllity and Related Attlitudes}

Largely driven by the rise in age at marriage, adolescent fertility rates have also been declining, from 84 live births for every 1,000 women ages 15 to 19 to 44 live births for every 1,000 women ages 15 to 19 between 1991 and 2013. This has positive implications for women's health, as risks of maternal and infant deaths are higher for young mothers.

Importantly, findings of a recent landscape analysis of family planning in Pakistan (Population Council, 2016) indicate that a sea change in attitudes towards childbearing is under way. Confronted with economic and social realities, youth (ages 16-20) interviewed are distinctly in favor of a smaller family size. Moreover, young peopleboys as well as girls, rural and urban, and in or out of school-have a very positive attitude towards family planning. They are quite knowledgeable about family planning and birth spacing and consider it necessary for maternal and child health as well as a better lifestyle. They are unequivocal in expressing the intention to use contraception after getting married.

\section{Sexual and Reproductive Health Information and Services}

In Pakistan's socio-cultural milieu, talking about sexuality and RH among young people is difficult, because of its sensitivity which makes it challenging to provide sex education to young people and build awareness especially about sexually transmitted infections (STIs). Despite the inclusion of youth in population and reproductive health strategies, interventions generally steer away from sex education for young people and youth-friendly health services. According to a Population Council study conducted among men aged 16-45 in six major cities-16\% reported having premarital sex making them vulnerable to STIs (Mir et al, 2013).

Hamid et al. (2010) identify the role of television as a source of peer education in the lives of youth and highlight the need to bring about attitudinal changes within the home and extended family environment so that young women and men's confusion and needs regarding sexuality can be addressed prior to marriage. The study finds that young women feel severely inhibited in their ability to ask questions about physical and related changes and they consider silence on women's health issues a part of being an adult woman. It is largely expected that young people will learn about sexual relations naturally after their marriage. The only source of more detailed information about sexual relations are married friends who share their own experiences; some women receive no information on sexual relations prior to their marriage. Since young women are allowed only to move in a social network that is judged as acceptable by the family, community-based initiatives could provide socially acceptable informal discussion groups where young women could meet to discuss sexuality, child bearing and other marriage-related issues and have their queries addressed.

Young men also report friends and the media as prominent sources of information about sexual development. Other less prominent sources of information include hakeems, television advertisements and radio discussions about contraception (Hennink et. al, 2005).

In interviews conducted during the landscape analysis (Population Council 2016), boys and girls specified the channels of information that should be used for different segments of their peers, e.g., educated, uneducated, rural, urban, etc. All youth, particularly those attending school, strongly suggested that family planning information be provided through the Internet. They also wanted to get information through social media, particularly Facebook, where they spend much of their leisure time, especially boys. Notably, boys were found to have more avenues than girls for such information, having greater access to mobile phones and to mass and social media. Our interviewers 
observed gender differences in access to information and communication technology (ICT): boys often owned their own mobile phones, and these were smart models that gave them access to the Internet and social media; on the other hand, girls usually had to borrow their parents' phones, which were usually older models that did not support Internet access. Youth also suggested that information be provided to them through mobile voice messages.

Girls (both school-going and out of school) suggested that the electronic media be utilized to provide family planning information, television for mainstream communities and radio for youth living in far-flung areas (Population Council 2016). Another important issue is the likely exclusion of young people from reproductive health services, especially if they are unmarried. While this is a generally healthy cohort with lesser morbidities from non-communicable diseases, there are vulnerabilities accruing from malnutrition, especially among adolescent girls; accidents; drug abuse; and risk of HIV/AIDS and STIs. Reproductive health services usually do not entertain young persons without family chaperones.

Moreover, in Pakistan very few health policies and programs for young people target specific socio-economic groups to address higher vulnerability in terms of either general or reproductive health (e.g., from poverty, drug abuse, belonging to broken families, etc.). Some such groups are in fact stigmatized and do not have access to appropriate information or services that could help reduce their vulnerability or improve their quality of life (World Population Foundation 2009). The exception may be young women (under 20) who 'fit in' within the acceptable norms of marriage and young women seeking antenatal and delivery related cares and services. This group of young aboutto-be-married adolescents are now less likely to face hindrances in antenatal and delivery care; use of these services in this group is now close to national averages, with $76 \%$ of expecting mothers receiving antenatal care and $49 \%$ having institutional deliveries.

\section{Political Participation and Empowerment}

On the political landscape of Pakistan, greater awareness, interest, and voice of youth is a clear emerging trend. There are 25 million registered next generation voters in Pakistan. Young people from the middle class who are exposed to several information networks are especially important drivers of change. There are now nearly 12 million young people in this class in Pakistan-young people who are more educated than their parents, marry later, live in better housing, earn incomes that have raised them above subsistence, and are connected by the media to each other and the rest of the world (British Council, 2013).

As would be expected, political parties and politicians are keen to enlist and involve this large vote bank. Political parties are also definitely beginning to recognize the importance of this demographic reality and are exploiting the larger numbers of youth as new voters that might actually step out of the mold of voting along with their parents and biraderi (clan). The number of seats for youth has increased in different political parties as well as in local government systems, with a special focus on female participation.

The rising role of youth in politics was especially notable in the last general elections in Pakistan. The 2013 elections were acknowledged to have established the important role of the large cohort of youth as an important emerging factor in national politics. The Jinnah Institute (2013) reported that the elections highlighted the tremendous potential the youth demographic holds for the state of politics in Pakistan. Analyzing data from the Election Commission and the National Database and Registration Authority (NADRA), the Sustainable Development Policy Institute (SDPI) reported that, according to electoral lists, 48\% of total voters in the 2013 elections were young voters (aged 18-30) (SDPI, 2013). 
With this new recognition and visibility, there is a huge potential for youth to place demands on those in power (or aspiring to be) and this can become a tool of empowerment. Programs in the future ought to capitalize on this route to empowerment and as a possible disruptor of traditional power bases.

According to the Jinnah Institute (2013), it is imperative in the interests of both democracy and the political system that youth, which comprises a majority cohort at present, be provided a greater voice and more substantive involvement in the political system. However, the possible risks of youth exploitation must be firmly avoided: Sabir and Zaman (2013) reports that in domestic political affairs, some political, ethnic and sectarian parties recruit youth at the college/university level to make them part of their "youth wings," which are used as party assets. Youth in such arrangements can be vulnerable to manipulation, and exposed to negative practices and violence. The Jinnah Institute (2013) warns that failure to improve the quality of political engagement with students and the youth in general could have a significant negative impact. Youth must be provided careful guidance so as to be able to utilize their political power for positive gains in terms of their wellbeing. 


\section{DIFFERENT KINDS OF YOUNG PEOPLE AND THEIR NEEDS}

Youth is a time of transition and the needs and capacities of young people change as they reach adulthood. Yet, while many development policies have started to express a special focus on youth, there is a tendency to ignore the dynamic nature of its needs. A useful way to come to grips with the flux within this group is to segment our understanding of youth demographics and needs by age group. In this section, we briefly analyze population data from the Population Council Revised population projections 2015 to present profiles of three subsets within the youth population-very young adolescents (10-14 years), adolescents (15-19 years), and older youth (20-24 years). We also look at how life trajectories vary across different segments of youth and how they have shifted since 2005 , and outline the indicated developmental priorities.

\section{Very Young Adolescents}

The youngest segment of adolescents entering the youth population is the cohort aged 10-14 years. Their number is estimated to have grown from 19.4 million in 2005 to 21.5 million in 2015.

The expectation would be that children of this age group should mainly be in school. However, while there are remarkable improvements in school enrollment in this age group, a large deficit persists. In 2005, out of about 10 million boys, only 7.2 million (72\%) were in schools, while out of 9.4 million girls, only 5.3 million (56\%) were in school. In total, about 7 million children of the 10-14 age group were out of school, of whom 1.7 million had joined the labor force (Figure 3.1).

In 2015, the situation has improved but remained far from ideal. Out of the 21.5 million children aged 10-14, 15.7 million were in school and 5.7 million children ( 2.3 million boys and 3.4 million girls) were out of school. Furthermore, child work is also down from 2.7 million in 2005-6 to 1.8 million in 2014-15 boys and girls participating in the labor force. Age-specific participation rates of this particular age group dropped down from $15.2 \%$ to $9.6 \%$ in the period 2005-06 to 2014-15 (Labor Force Survey 2005-06 \& 2014-15).

However, it is of concern that as many as 3 million girls and 1.6 million boys are neither in school nor working (Figure 3.1). They include those who never attended school, or drop outs with very little or no opportunity of acquiring any skills or self-esteem leading up to adulthood.

Fortunately, rising age at marriage has reduced the number of married girls in this age group to 100,000 , which is half the number in 2005. In absolute terms, these young girls are concentrated in certain areas and pockets of Pakistan and have to be protected from hazardous child marriages.

The main interventions required to address the concerns of this group are to ensure (a) entry into primary school; (b) continuation of post-primary education and prevention of dropping out from school; c) prevention and protection against child labor and child marriage. Any strategy must have a gendered approach as girls are several fold more vulnerable and their life courses much more likely to change in this age group. 
Figure 3.1: Estimated Numbers of Adolescent Boys and Girls (aged 10-14) by Their Current Activity Status Pakistan 2005 and 2015

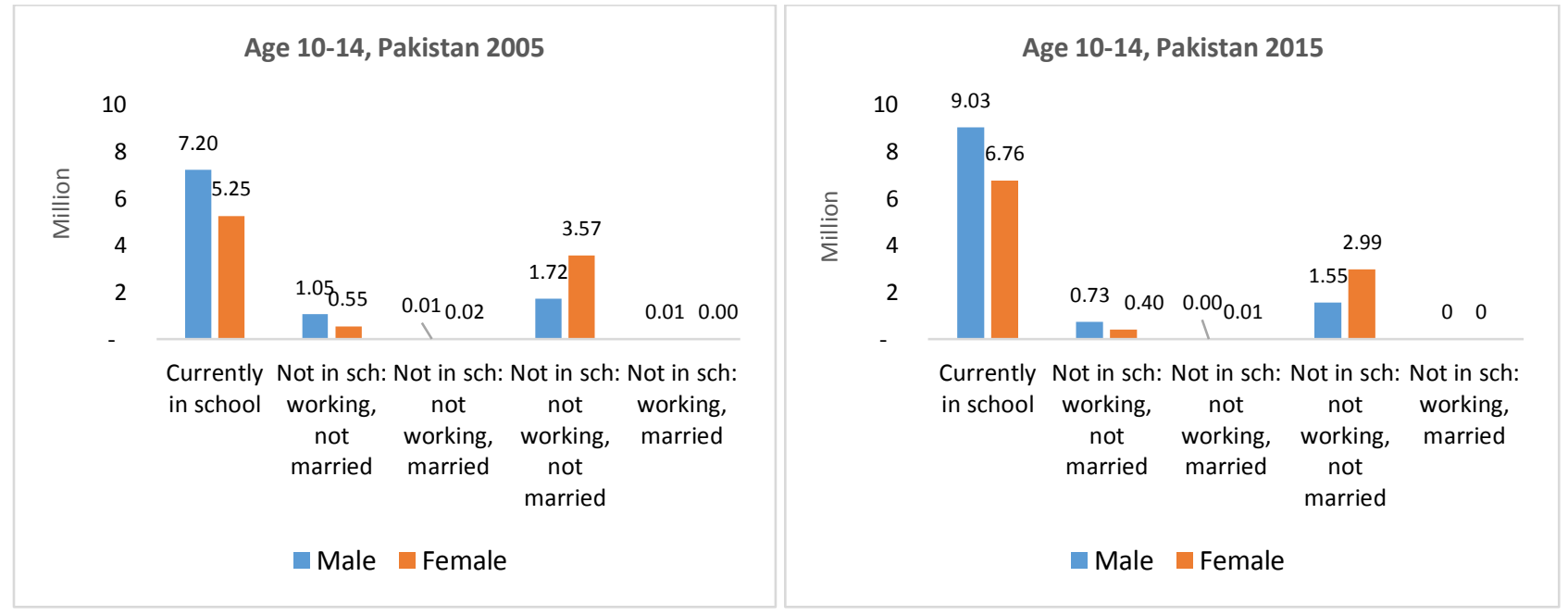

Source: PSLMS 2004-05 \& 2014-15

\section{Adolescents}

The population of adolescents aged 15 to 19 was estimated at 17.5 million in 2005 (9 million boys and 8.5 million girls) and 20.4 million in 2015 (10.7 million boys and 9.7 million girls). The news, once again, is partially good and partially bad.

In 2005, out of 17.5 million children, only 5.9 million children (34\%) (3.5 million boys and 2.4 million girls) were in school, and the rest were out of school. Of these 11.6 million, about 4.5 million (3.6 million boys and 0.9 million girls) were working, including as unpaid family helpers. About one million girls in this age group were married and another 4.1 million girls were "Not in School: not working, not married," reflecting a big contrast in the lives of boys and girls.

By 2015 there was a visible improvement in the proportions attending school. In 2015, 43\% percent of the population of this particular group was attending school (any educational institution), almost a $10 \%$ increase since 2005, when this percentage was 34, while it is heartening to note that there are as many girls in school in 2015 as there were boys in school in 2005-even so, many more boys still benefit from schooling than girls (Figure 3.2).

The increase in school attendance among older adolescents (15-19 years) is especially an achievement: the rising numbers not only reflect an increase in the proportions attending school but also indicate a deceleration in the rise in population numbers.

The number of married girls has fallen slightly from 1.0 million in 2005 to 900,000 in 2015. While still too high, the numbers in the amorphous category of "not in school: not married, not working" have remained static, which is due to the lower proportions falling into this group.

The priority actions for this group are certainly complex and challenging. The ideal state for this group of young people would be to be acquiring secondary education and beyond and improving their skills and propensities to seek paid employment. This may be the most important age group on which to focus in terms of giving the maximum 
possible opportunities through the maximal number of channels-school, mass media, mobile phones, sports, internship schemes, girl guides/scouts, community and civic participation. Out of school schemes such as informal education, financial literacy learning and innovations to involve those who are not exposed to the channels mentioned above may be the ones where investments are most likely to pay off to prevent the exclusion of the poorest young people from the benefits of development.

Child protection in terms of stopping marriages below the ages of 18 is certainly important. Interventions to build life and family skills and awareness of marriage and reproductive health aspects could be introduced more effectively for this age group, especially through premarital counseling. The media, Internet and social media, which are already playing a significant role in building awareness among young people, can be used even more effectively and widely. Equally important are efforts for protection against hazardous and informal employment to which this group is likely to be exposed.

Figure 3.2: Estimated Numbers of Adolescent Boys and Girls (aged 15-19) by Their Current Activity StatusPakistan 2005 and 2015

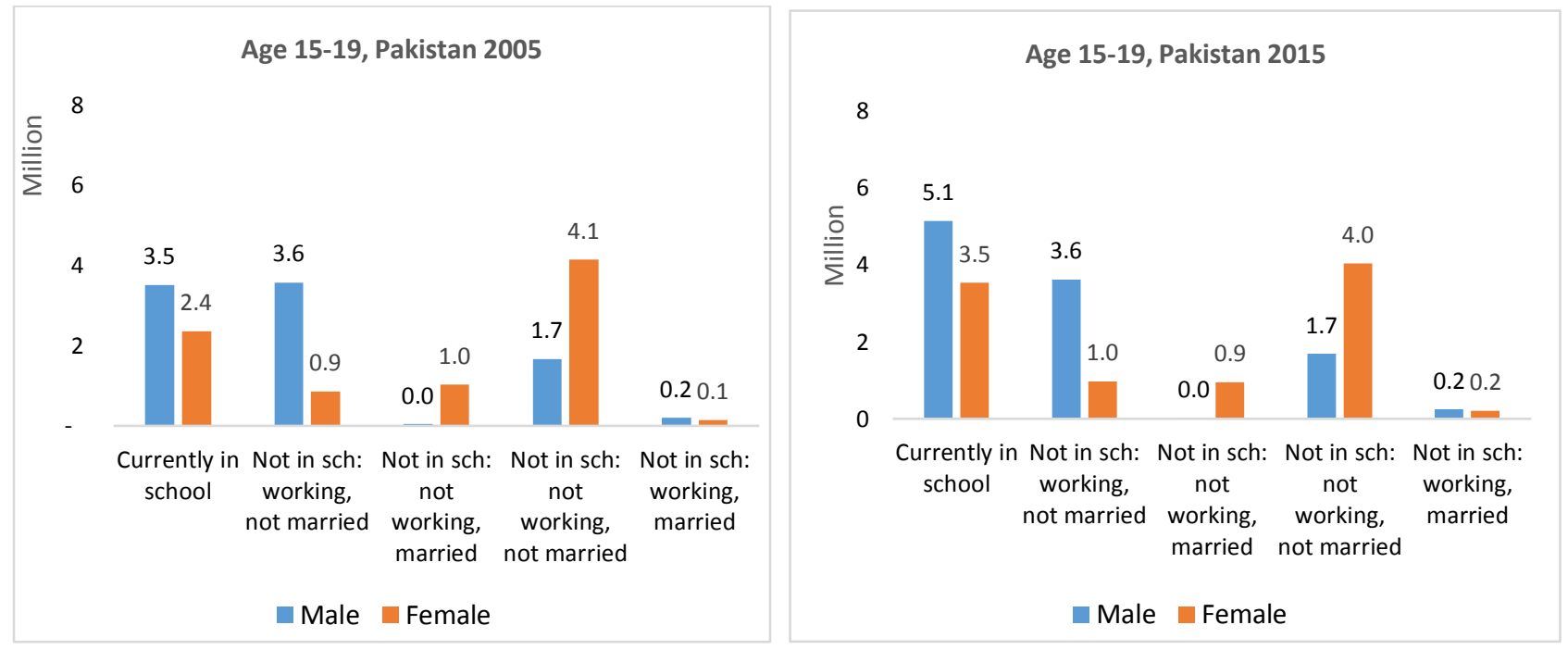

Source: PSLMS 2004-05 \& 2014-15

\section{Older Youth}

The trends and differentials pointed out for the 15-19 year cohort become more exaggerated for 20- to 24-yearolds. In 2005, the latter cohort comprised 14.6 million ( 7.5 million males and 7.1 million females) and, by 2015 , due to changing age structures, 4.2 million more young people had been added, increasing the total population of this cohort to 18.8 million (9.7 million boys and 9.1 million girls).

As pointed out, this cohort is transitioning from dependency to actual economic contribution, and only 0.9 million males and 0.5 million females are currently studying. In a way this was the core group entering adulthood in 2015. It is the time of the greatest likelihood of completing significant transitions, most notably work, marriage, and parenthood.

In this age group, both male and female youth have high aspirations and they seek employment or may be in employment. According to the Labor Force Survey 2014-15, the unemployment rate for this particular age group (both sexes combined) at $11 \%$ is the highest among all other age groups, almost double of the national all-ages average. Unemployment among females, at $16.4 \%$, also peaks in this age group. This reflects the large and growing 
gap between aspirations of young persons and available job opportunities, and is an urgent concern, not only for youth, but also for the wider economic goal of reaping the demographic dividend, since the only way to do so is to optimize employment among young people, especially females.

A major gender split is reflected by the fact that out of a total 9.7 million male youth aged $20-24,4.7$ million are unmarried and working and an additional 1.5 million are still studying. In contrast out of 9.1 million females aged 20-24, the major bulk of women-3.9 million-are married and an additional 2.7 million unmarried women are neither in school nor working. Both these groups have increased in size since 2005 when corresponding figures were 3.5 and 2.1 million (Figure 3.3). Efforts to increase work force participation among young women are likely to have not only economic benefits (such as contributing towards household savings) but also social benefits, such as empowerment of women to have a say in family decisions as well as a greater appreciation of their importance in households.

This is also an important age group for open and detailed communication, as well as proactive service provision related to family planning and other aspects of maternal and child health. Engaging men and women at the start of their married lives, and ensuring that they are informed enough to make healthy choices can have a transformative impact in terms of reducing morbidity and mortality, and enabling couples to match family sizes with their means and child-raising aspirations.

Figure 3.3: Estimated Numbers of Adolescent Boys and Girls (aged 20-24) by Their Current Activity Status-Pakistan 2005 and 2015

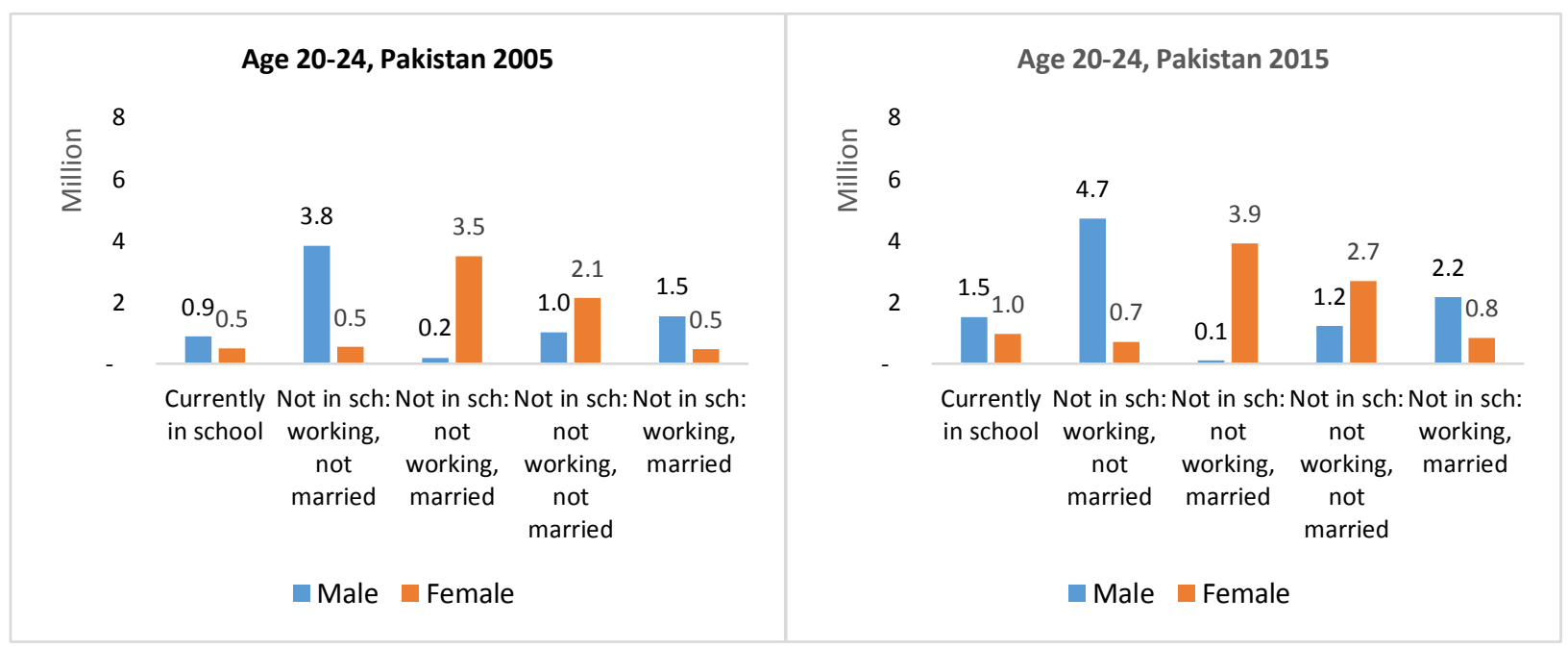

Source: PSLMS 2004-05 \& 2014-15

\section{Llfe Trajectory Differences among Youth by Gender and Residence}

In the following graphs (Figures 3.4), we have plotted the life trajectories of adolescents based on the PSLMS 201415 data depicting the most current scenario, which classifies young people in four mutually exclusive categories by three age groups. These four categories are:

i. Currently in school (Green)

ii. Not in school: working, not married (Yellow)

iii. Not in school: not working, married (Blue)

iv. Not in school: not working, not married (Red) 
If we compare the trajectories in the lives of boys and girls in 2005 (Figure 3.4), about three-fourths of boys aged 10-14 were currently enrolled at that time and slightly above half of the girls were enrolled as well. However, with advancing age, the enrollment rates for girls drop sharply compared to boys. The blue shade (Not in school: not working, married) and the red shade (Not in school: not working, not married) are more prominent and likely state for a large proportion of girls.

There is progress to report over time. Over the period (from 2005 to 2015), there has been an 8-percentage-point enrollment increase for boys aged 10-14, and 11 percentage-point increase for girls. The situation of 20-24 year olds has not changed much; in fact much the same percentage of girls in 2015 (32\%) are Not in school: not working, not married as a decade ago.

Urban-rural differences are also of significance. Urban young people definitely have better chances of schooling and later marriage compared to rural areas (Figure 3.5). In addition, gender differences are also less prominent in urban areas: If we compare boys to girls in urban areas, the same proportion of $10-14$ years old $(86 \%)$ are currently in school. However, the differences in work persist-about 58\% of males aged 20-24 are working and not married, while only $8 \%$ of females in the same age group is engaged in work. In rural areas, gender differences are starker with limited opportunities for both boys and girls; as a result the latter are more likely to fall behind.

The above analysis makes evident the need to understand the different age groups among youth and to tailor interventions to their specific requirements, in particular taking into account age, gender, urban/rural residence, provincial location, and socioeconomic status. Giving youth a sound foundation for adulthood requires not only a multi-sectoral approach but also a thorough appreciation of the diversity of circumstances, capacities and needs that this cohort represents. 
Figure 3.4: Life Trajectory Differences among Youth (10-24 years) by Gender - Pakistan 2005 and 2015

\section{5}

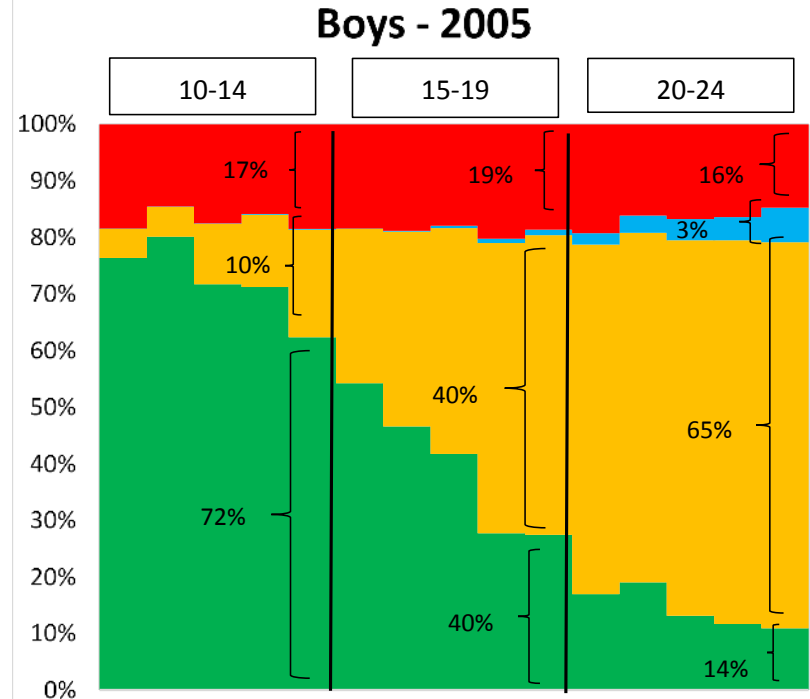

$\begin{array}{lllllllllllllll}10 & 11 & 12 & 13 & 14 & 15 & 16 & 17 & 18 & 19 & 20 & 21 & 22 & 23 & 24\end{array}$

Not in sch: not working, not married

Not in sch: not working, married

Not in sch: working, not married

Currently in school

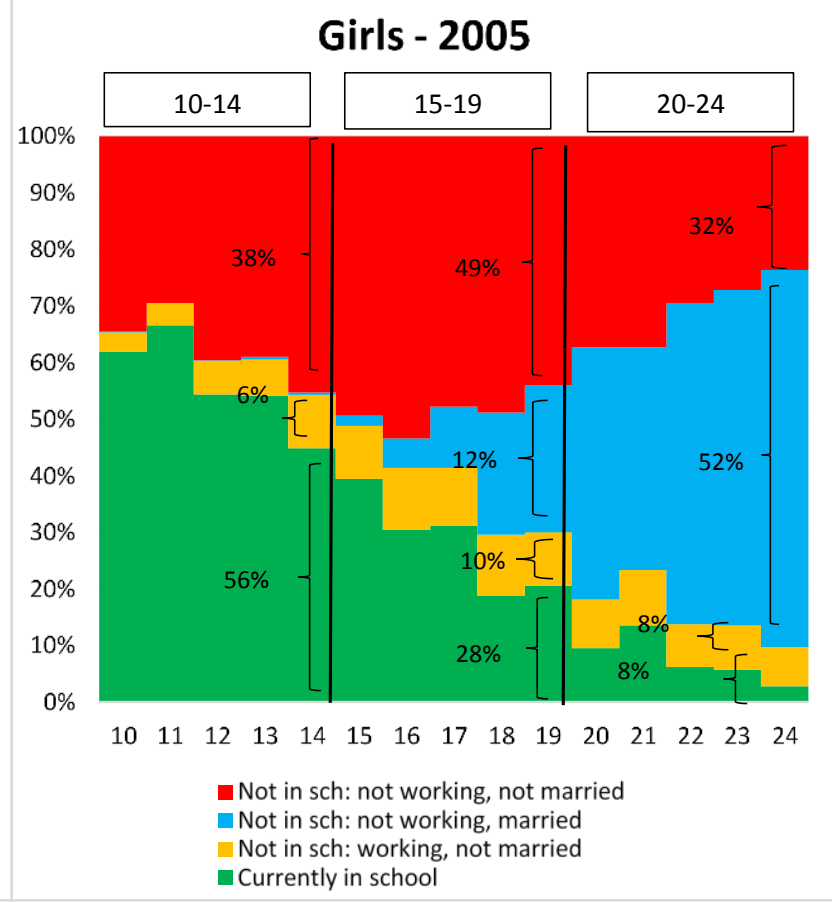

$\underline{2015}$

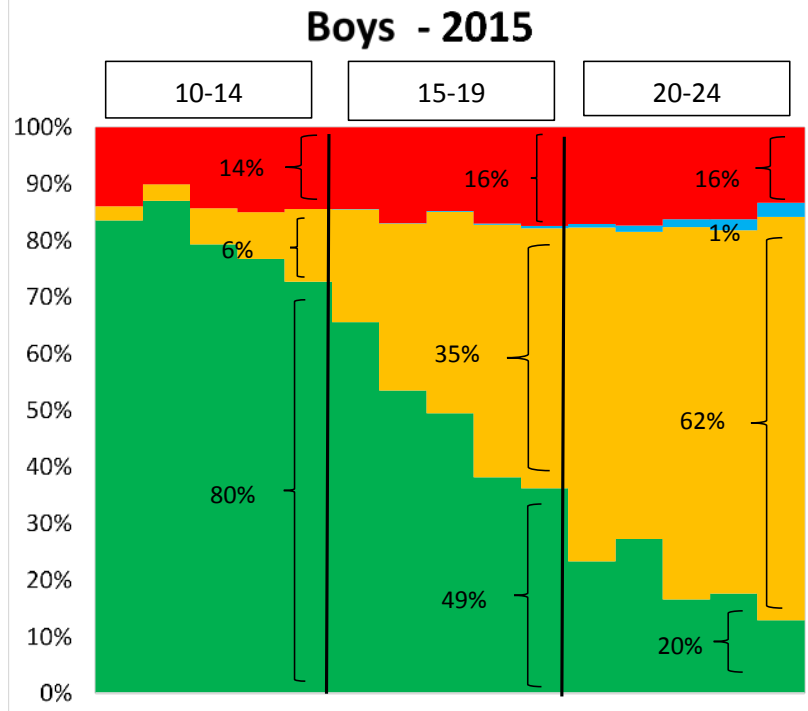

$\begin{array}{lllllllllllllll}10 & 11 & 12 & 13 & 14 & 15 & 16 & 17 & 18 & 19 & 20 & 21 & 22 & 23 & 24\end{array}$

Not in sch: not working, not married

Not in sch: not working, married

Not in sch: working, not married

- Currently in school

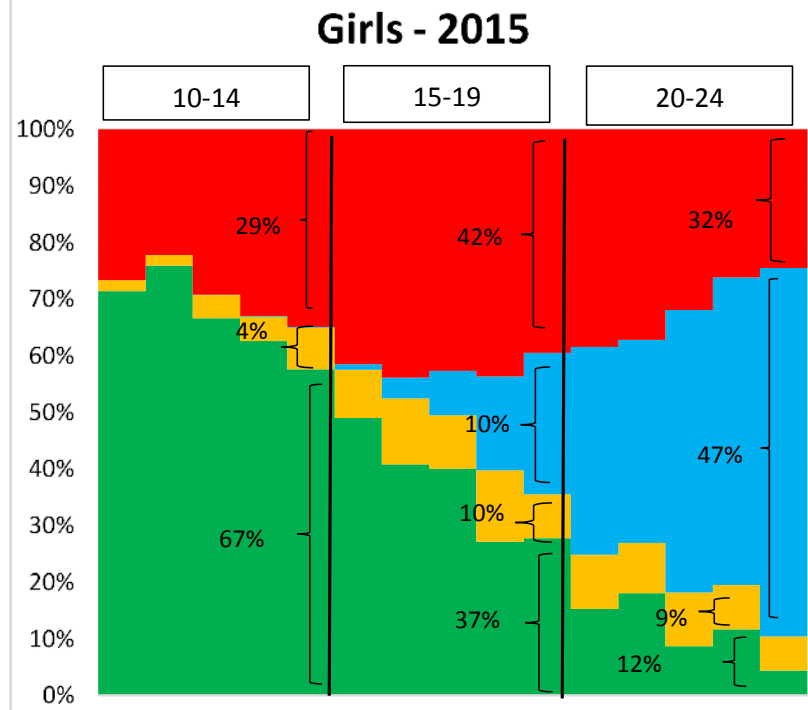

$\begin{array}{lllllllllllllll}10 & 11 & 12 & 13 & 14 & 15 & 16 & 17 & 18 & 19 & 20 & 21 & 22 & 23 & 24\end{array}$

Not in sch: not working, not married

Not in sch: not working, married

Not in sch: working, not married Currently in school 
Figure 3.5: Life Trajectory Differences among Youth (10-24 years) by Gender and Residence - Pakistan 2015

\section{Boys \& Girls - Urban 2015}
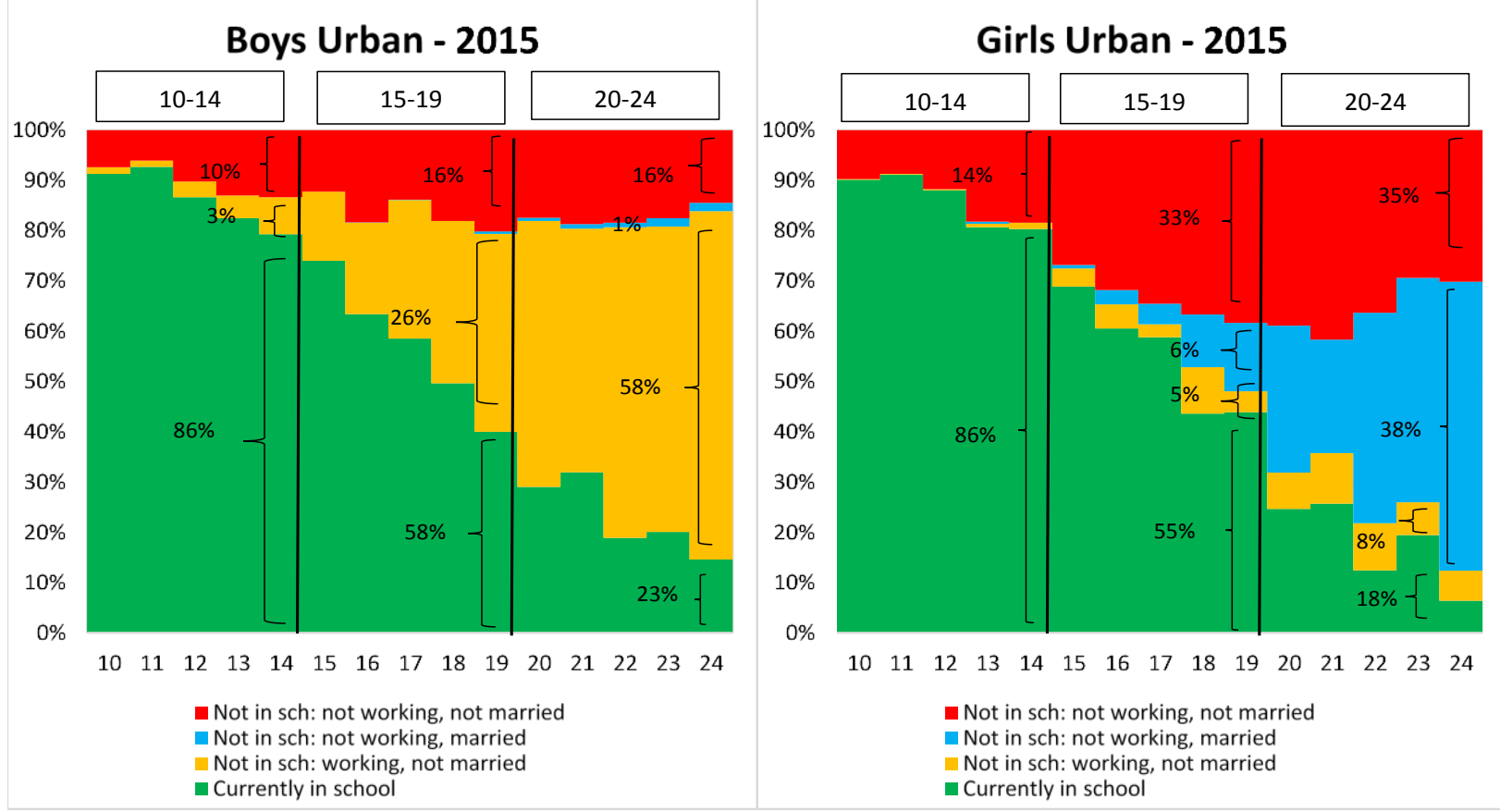

\section{Boys \& Girls - Rural 2015}
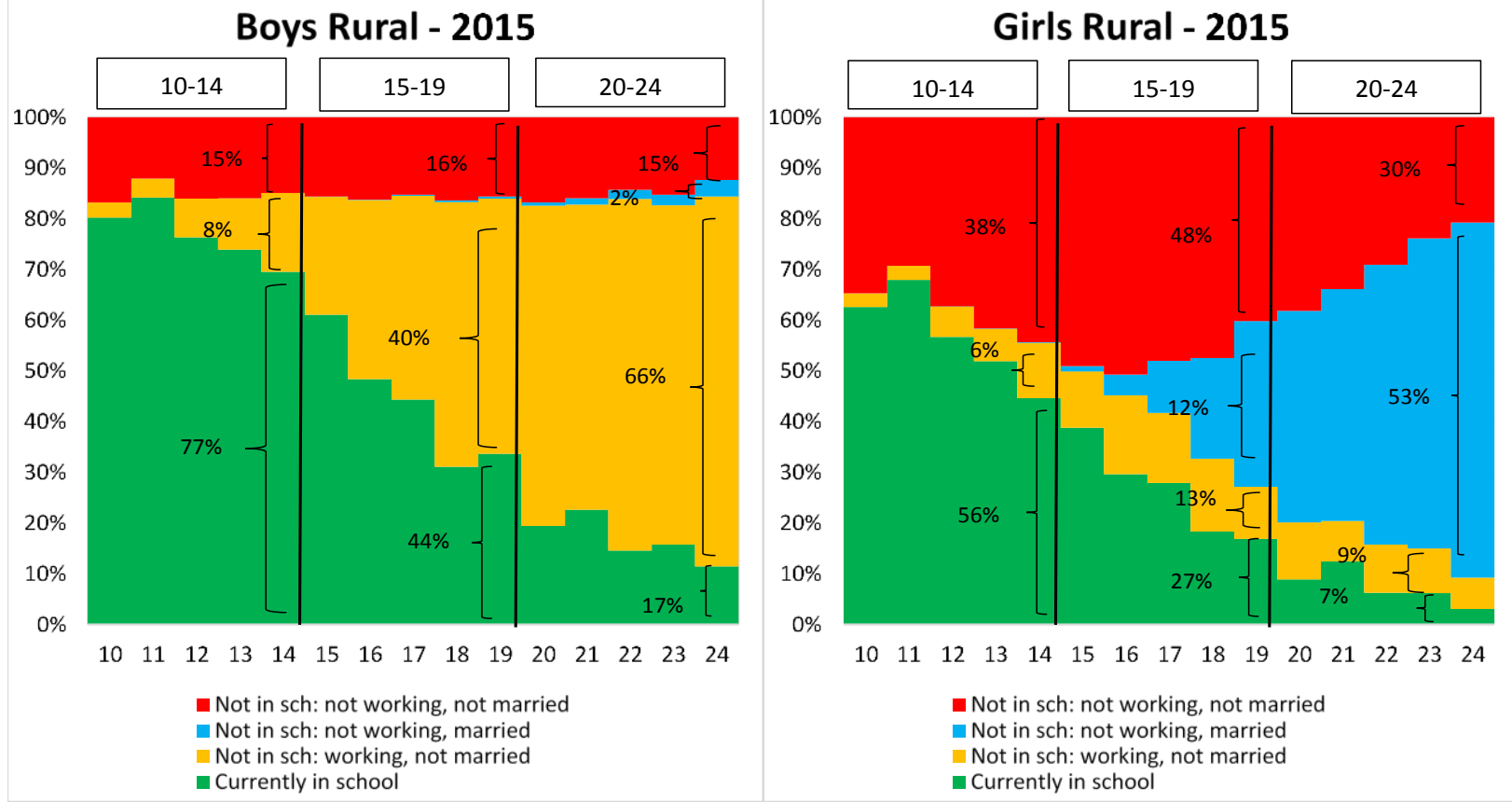

Source: PSLMS 2004-05 \& 2014-15 


\section{THE RESPONSES THUS FAR - GOVERNMENT, NGOS AND DONORS}

This section briefly reviews the extent to which the prerogatives of youth development and participation are recognized in different policies and strategies of the federal and provincial governments, and addressed in government and non-governmental interventions.

\section{Youth In Publlc Pollcles and Strategles}

The major policy and strategy documents that have a bearing on youth development and participation include Pakistan 2025 - One Nation, One Vision (commonly known as Vision 2025) at the national level, and youth policies, population policies, health strategies, and employment and growth or development strategies at the provincial level.

\section{Paklstan Vislon 2025}

Developed by the Planning Commission in 2013, Government of Pakistan in consultation with provincial governments and a broad range of other stakeholders, Vision 2025 represents a unified, nationally owned perspective of priorities and approaches for development till 2025. It sets the ambitious target of making Pakistan amongst the top 25 economies of the world and upper middle country by 2025 and ultimately one of the 10 largest economies by 2047 , which implies a heavy focus on positioning youth to fulfill the objectives associated with all vision elements. Vision 2025 does talk about young people in the context of education, employment, labor market efficiency, skill development, and sports; a particularly encouraging aspect is its focus on development of knowledge economy of youth through improvements for higher education attainment, advancement in information and communication technology, and reforms in Pakistan's labor market to develop a demand-based skilled workforce.

However, the document is limited in its inclusion of the special needs of youth in the contexts of general and reproductive health, gender issues, life skills, civic and political participation, and social security. This oversight has important implications for adolescents and older youth who are now making the transition to adult roles as spouses, parents, and workers; recognizing the issues that could deflect these young lives off-course would be the first step in ensuring that the next generation is able to realize our national aspirations. More comprehensive strategies must be carefully crafted and expressly included in the Vision 2025 to seize the narrow window of opportunity to set as much of the youth population as possible on the path to personal and collective success.

\section{Youth Pollcles}

At the national level, the last policy for youth (15-29 years) was formulated in 2008. Since then, under the 18th Constitutional Amendment, matters of youth development have been devolved to provincial governments, precluding the need for a national youth policy. With respect to administration, currently no federal ministry or other national level organization or association has been mandated to spearhead efforts for youth. However, all provinces have developed their youth policies, essentially on the pattern of the 2008 national policy. The youth policies of Punjab and Khyber Pakhtunkhwa have been approved (in 2012 and 2016, respectively) but Sindh and Balochistan still have draft policies (dated 2016 and 2015, respectively). These youth policies have been developed by the provincial departments of "Youth Affairs, Sports, Archaeology and Tourism" in Punjab, "Environment, Sports and Youth Affairs" in Balochistan, "Sports, Tourism, Culture, Archaeology, Museums and Youth Affairs" in KP, and "Sports and Youth Affairs" in Sindh.

A positive aspect of these policies is that they recognize the pressure of the youth bulge, as well as the inherent opportunity of a demographic dividend. Also encouraging is the coverage of multiple spheres of development in the policies, including economic, social, health, and education, as well as political development and volunteerism, with 
the stated intention of empowering youth. This is an improvement over past policies, the focus of which tended to be limited to reproductive health, sports, and education.

However, there are some continuing weaknesses in the present youth policies. The first major weakness pertains to scope: while the policies generally reflect adequate appreciation of the need to address and engage youth in economic development, skill development, education, and political development, other important areas, such as general health, family planning, life skills, social security and financial support, are either missing or only superficially dealt with.

The second weak area relates to responsiveness to the diversity within the youth cohort and its implications. The current youth policies are generally blind to differences of gender, wealth, urban/rural residence, and age among youth. As the discussion in the previous section indicates, this near-absence of segmentation can only lead to blunt strategies that are unlikely to work. However, there are some noteworthy exceptions. The draft youth policy of Balochistan expresses a greater awareness of gender disparities through its special focus on education, employment, and credit opportunities for young women. Likewise, in Punjab, the draft "Adolescent (10-19 years) Strategy and Strategic Plan 2013-17" reflects the government's awareness of the special needs of adolescents and younger youth, albeit only with respect to awareness of sexual and reproductive health issues. The other three provinces have not given any special attention to this crucial age group, which is of concern.

A third major issue is the apparent gap between the aims expressed in the youth policies, and the strategies proposed to achieve those aims. In some cases, the strategies indicated in the documents are inadequate for achieving stated objectives. For example, the aim of empowering youth is conservatively linked with raising awareness amongst youth about their rights, with no further steps defined to provide youth an enabling environment to broaden their vision, explore their potentials, or participate in platforms where they have a say. Similarly, strategies for providing employment opportunities to youth are insufficient and limited to providing small loans, internships, and entrepreneurship opportunities, creating job banks, etc., missing the larger picture of how to mainstream youth in the job market and create opportunities to absorb the burgeoning young male and female work force. Unless this broader issue is addressed, the steps to support youth employment are unlikely to have any significant effects in coming years.

For some challenges, policies indicate a very broad approach and fail to chalk out a clear strategy. This is especially apparent in the issue of age at marriage, for which policies claim that "measures" will be taken to implement the law but do not specify any further details; indeed, Balochistan's draft policy hardly talks about this subject. Another likely stumbling block to implementation is the lack of linkages and integration of youth policies with the main development strategies, such as Vision 2025 and related provincial policies, strategies and plans.

An encouraging recent example of a youth-specific law is the ordinance issued by the Punjab government on July 2016, which bans the employment of children (15-18 years) in hazardous occupations. This law also seeks to protect children and adolescents against any form of slavery, such as their sale and human or drug trafficking, debt bondage and serfdom, and prostitution (Government of Punjab, 2016).

\section{Population Pollcles}

Provincial population policies of Punjab, Sindh and Balochistan are currently at the draft stage whereas the policy of KP has been approved. The policies of Punjab (2016) and (Sindh) give sufficient attention to youth issues, focusing not only on family planning services but also on age at marriage, general and reproductive health, education, gender issues, empowerment, skill development, and life skills. However, the population policy of KP (2015) considers youth only from the perspective of family planning and general health and makes only a slight reference to adolescents. It otherwise focuses primarily on the currently married population. 
Although the population policy of Balochistan talks about youth needs pertaining to age at marriage, sexual and reproductive health, employment, education, skill development and gender, no strategy has been defined for meeting these needs. Surprisingly, despite being a population policy, the document does not refer to family planning services, information, or awareness for youth; the topic of family planning for youth is missing altogether, though it is covered in all other provincial population policies.

\section{Health Strategles}

In the health strategies of all provinces, there is no mention of the special needs of youth, suggesting low awareness of youth needs and of the advantages of youth-centered approaches, as well as the perception that youth issues are to be addressed by the dedicated departments rather than as a cross-cutting theme. However, youth health needs are addressed in the minimum service delivery standards (MSDS) for health care in Punjab and KP. Notably, Punjab's focus is limited to health and health education and ignores other related important aspects, such as age at marriage, family planning, sexual health, while these are incorporated in KP's MSDS, which recognize the interconnectivity of these issues for youth.

\section{Economlc Development Strategles}

Economic development strategies of the major provinces are documented in the "Punjab Growth Strategy (2018)"; KP's “Integrated Development Policy (2014-18)"; the "Sindh Strategy for Sustainable Development (2007-2017)"; and the draft "Balochistan Development Vision and Strategy (2014)."

The Punjab Growth Strategy pays considerable attention to youth, specifically to their education, skill development, and employment opportunities, but it still lacks a broader focus on youth empowerment. It also pays inadequate attention to job creation for rural and female youth.

KP's Integrated Development Policy (2014-18) completely ignores issues of general and sexual and reproductive health of youth, life skills, and political empowerment, but pays sufficient attention to engaging youth in employment (including self-employment schemes), skill development, education, and sports, with a focus on gender aspects.

The scope of the Sindh Strategy for Sustainable Development (2007-2017) includes energy, water, agriculture, rangeland, biodiversity, fisheries, etc. It also focuses on engagement of youth through education, population and health, gender, communication, and information and communication technology (ICT) interventions. However, it does not specially talk about youth's economic and skill development or political empowerment.

The draft Balochistan Development Vision and Strategy (2014) includes the wider economic concerns in the province, specifically growth sectors, the potential for growth centers, and the development of an economic corridor, but does not discuss youth.

In the absence of a national employment policy, the latest labor policy (2010) was also reviewed. Unfortunately, youth is given little attention in this policy-only to the extent of mentioning that youth between 14 and 18 years of age may not be engaged in hazardous labor. A positive aspect of the labor policy is its strong focus on women's empowerment and gender equality, but it does not contain special provisions for youth in terms of rights, skill development, or even manpower export.

\begin{tabular}{l|l}
\hline Policies and strategies generally focus on: & Policies and strategies generally ignore: \\
- Skill development & - Marriage and rights \\
- Employment opportunities & Life skills development \\
- Education & Health and reproductive health \\
$-\quad$ Gender equality \\
$-\quad$ Civic and political engagement /empowerment \\
$-\quad$ Special needs of poor, rural, and uneducated youth
\end{tabular}


Tables 4.1 and 4.2 summarize the foregoing discussion of coverage of youth issues in relevant policies and strategies. Overall, apart from youth policies that have to be developed purely for youth, no other policies and strategies focus on youth as a special cohort or priority. The existing policies and strategies, including the youth policies, do not cover the full range of aspects that require attention. Perhaps one of the most glaring omissions is the failure of health strategies to mention the needs of youth, especially adolescents, which are very different from those of other population subgroups. Similarly, while population policies mention youth, and refer to services for adolescents as well as the issue of early marriage, they do not incorporate youth concerns in other areas such as migration.

Moreover, there is no visible coordination between different departments and sectors for a collective effort for youth. Any special attention to youth revolves for the most part around skill development, education, and small-scale employment opportunities, with less emphasis on issues such as health and reproductive health, age at marriage, life skills, volunteerism, social security networks, etc. There appears to be a shared concern to prepare youth for their economic roles, but not so much for their social development or wider empowerment.

Table 4.1: Mention of Youth Issues in Youth Policies and Vision 2025

\begin{tabular}{l|c|c|c|c|c}
\hline \multirow{2}{*}{ Youth Issues } & \multicolumn{5}{c|}{ Youth Policies } \\
\cline { 2 - 6 } General health & Sindh & KP & Punjab & Balochistan & Vision 2025 \\
\hline Sexual and reproductive health & $\checkmark$ & $\checkmark$ & $\checkmark$ & $\checkmark$ & \\
\hline Family Planning & $\checkmark$ & $\checkmark$ & $\checkmark$ & $\checkmark$ & \\
\hline Employment & $\checkmark$ & $\checkmark$ & $\checkmark$ & $\checkmark$ & \\
\hline Education & $\checkmark$ & $\checkmark$ & $\checkmark$ & $\checkmark$ & $\checkmark$ \\
\hline Skill development & $\checkmark$ & $\checkmark$ & $\checkmark$ & $\checkmark$ & $\checkmark$ \\
\hline Sports & $\checkmark$ & $\checkmark$ & $\checkmark$ & $\checkmark$ & $\checkmark$ \\
\hline Youth empowerment & $\checkmark$ & $\checkmark$ & $\checkmark$ & $\checkmark$ & \\
\hline Financial intervention & $\checkmark$ & $\checkmark$ & $\checkmark$ & & $\checkmark$ \\
\hline Gender & & & $\checkmark$ & $\checkmark$ & \\
\hline Politics & $\checkmark$ & $\checkmark$ & $\checkmark$ & $\checkmark$ & \\
\hline Social security networks & $\checkmark$ & $\checkmark$ & $\checkmark$ & $\checkmark$ & \\
\hline Family and life skills & & $\checkmark$ & & $\checkmark$ & \\
\hline Volunteerism and community services & $\checkmark$ & $\checkmark$ & $\checkmark$ & $\checkmark$ & \\
\hline
\end{tabular}


Table 4.2: Mention of Youth Issues in Population and Health Policies and Development Strategies

\begin{tabular}{|c|c|c|c|c|c|c|c|c|c|c|c|}
\hline \multirow[b]{3}{*}{ Youth Issues } & & & & & \multicolumn{3}{|c|}{ Health Policies } & \multicolumn{4}{|c|}{ Economic Development Strategy } \\
\hline & \multicolumn{4}{|c|}{ Population Policy } & $\begin{array}{l}\text { Health } \\
\text { Strategy }\end{array}$ & \multicolumn{2}{|c|}{$\begin{array}{l}\text { Minimum health } \\
\text { service delivery } \\
\text { standards }\end{array}$} & \multirow{2}{*}{$\begin{array}{l}\begin{array}{l}\text { Growth } \\
\text { Strategy }\end{array} \\
\text { Punjab }\end{array}$} & \multirow{2}{*}{$\begin{array}{c}\begin{array}{c}\text { Integrated } \\
\text { Developme } \\
\text { nt Policy }\end{array} \\
\text { KP }\end{array}$} & \multirow{2}{*}{$\begin{array}{c}\text { Strategy for } \\
\text { Sustainable } \\
\text { Development } \\
\text { Sindh }\end{array}$} & \multirow{2}{*}{$\begin{array}{c}\text { Balochistan } \\
\begin{array}{c}\text { Development Vision } \\
\text { and Strategy }\end{array} \\
\text { Balochistan }\end{array}$} \\
\hline & Punjab & Sindh & KP & Balochistan & \multirow{17}{*}{ 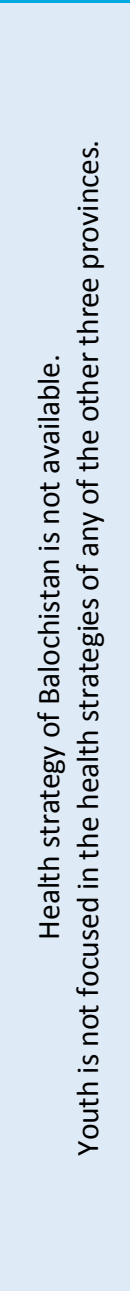 } & Punjab & KP & & & & \\
\hline Age at marriage & $\checkmark$ & $\checkmark$ & & $\checkmark$ & & & $\checkmark$ & & & & \multirow{16}{*}{ 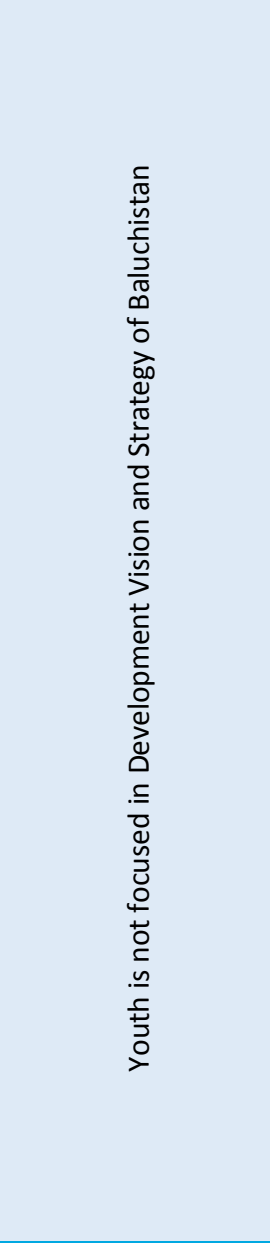 } \\
\hline Health & $\checkmark$ & $\checkmark$ & $\checkmark$ & & & $\checkmark$ & $\checkmark$ & & & $\checkmark$ & \\
\hline General health & $\checkmark$ & $\checkmark$ & $\checkmark$ & & & & & & & & \\
\hline $\begin{array}{l}\text { Sexual and } \\
\text { reproductive } \\
\text { health }\end{array}$ & $\checkmark$ & $\checkmark$ & & $\checkmark$ & & & $\checkmark$ & & & & \\
\hline Family planning & $\checkmark$ & $\checkmark$ & $\checkmark$ & & & & $\checkmark$ & & & & \\
\hline Employment & $\checkmark$ & $\checkmark$ & & $\checkmark$ & & & & $\checkmark$ & $\checkmark$ & & \\
\hline Education & $\checkmark$ & $\checkmark$ & & $\checkmark$ & & & & $\checkmark$ & $\checkmark$ & $\checkmark$ & \\
\hline Skill development & $\checkmark$ & $\checkmark$ & & $\checkmark$ & & & & $\checkmark$ & $\checkmark$ & & \\
\hline Sports & & & & & & & & & $\checkmark$ & & \\
\hline Empowerment & $\checkmark$ & $\checkmark$ & & & & & & $\checkmark$ & $\checkmark$ & & \\
\hline $\begin{array}{l}\text { Financial } \\
\text { intervention }\end{array}$ & & & & & & & & & $\checkmark$ & & \\
\hline Gender & $\checkmark$ & $\checkmark$ & & $\checkmark$ & & & & $\checkmark$ & $\checkmark$ & $\checkmark$ & \\
\hline \multicolumn{10}{|l|}{ Politics } & & \\
\hline $\begin{array}{l}\text { Social security } \\
\text { networks }\end{array}$ & & & & & & & & & & & \\
\hline $\begin{array}{l}\text { Family and life } \\
\text { skills }\end{array}$ & $\checkmark$ & $\checkmark$ & & & & & & & $\checkmark$ & & \\
\hline $\begin{array}{l}\text { Volunteerism and } \\
\text { community } \\
\text { services }\end{array}$ & & $\checkmark$ & $\checkmark$ & & & & & & & & \\
\hline
\end{tabular}




\section{Government Inltlatives for Youth}

In recent years, the federal and provincial governments have launched a number of initiatives to empower youth, which are listed below (Table 4.3). There are a few "Prime Ministers' initiatives" for youth aimed at developing the skills of youth, providing them loans for businesses, reimbursing their fees, and giving them internship opportunities. For the most part, these efforts are targeted at unemployed, less educated, and unprivileged/poor youth, and there is a conscious focus on gender equality. These are very positive steps that indicate the federal government's concern for youth development. However, the scope of assistance to youth is limited to education and economic development, while all other important areas, such as health, reproductive health, family planning, sports, and particularly politics are neglected.

Across the provinces, Punjab is in the lead in introducing new schemes for youth and the main focus is aligned with the focus of federal government youth schemes. Sindh also has a number of major youth initiatives and encouragingly the main focus of these is to develop leadership skills and empowerment among youth. Both sets of schemes give special attention to different youth segments, taking into account needs based on gender, low socioeconomic status, and access to formal and informal education sectors. However, initiatives to develop life skills, build health and family planning awareness, and encourage volunteerism, sports, and youth's positive political participation are lacking.

On the other hand, KP and Balochistan have hardly introduced any initiatives for youth. In KP, the main focus is on imparting technical skills to youth and supporting unemployed youth through stipend programs. Balochistan's efforts to empower youth are also limited to developing their computer skills. There is a need to expand government interventions for youth in the two provinces.

\section{Table 4.3: Youth Empowerment Initiatives of the Federal and Provincial Governments}

\begin{tabular}{|c|c|}
\hline Program & Year \\
\hline \multicolumn{2}{|l|}{ Government of Pakistan } \\
\hline Prime Minister's Youth Skills Development Program & 2013-2016 \\
\hline Prime Minister's Youth Training Scheme & $2015-2018$ \\
\hline Prime Minister's Youth Business Loan Scheme & 2013-2016 \\
\hline Prime Minister's Fee Reimbursement Scheme & 2015- \\
\hline Prime Minister's Youth Internship program & 2016 \\
\hline \multicolumn{2}{|l|}{ Government of Punjab } \\
\hline Laptop Awards Program & 2013-2018 \\
\hline Danish School and Centers of Excellence Authority & 2010- \\
\hline Punjab Education Endowment Funds (PEEF) & 2012-2016 \\
\hline Upgrading of Institutions of Special Education & Not available \\
\hline Market-oriented and Skills-based Subjects for Deeni Madaris (Religious schools) & Not available \\
\hline Self-Employment and Entrepreneurship Promotion & Not available \\
\hline Punjab Women Empowerment Package & 2012- \\
\hline Punjab Skills Development Fund & 2011- \\
\hline Special Initiative for Youth in Jails & Not available \\
\hline Vocational Training Programs & 2014- \\
\hline
\end{tabular}




\begin{tabular}{l|l}
\hline Program & Year \\
\hline Cab Scheme for Unemployed Youth & 2015 \\
\hline Government of Sindh & $2008-$ \\
\hline Benazir Bhutto Shaheed Youth Development Program & 2012 \\
\hline Establishment of Mobile Skill Development Unit for Underprivileged Youth (EMSDUUY) & $2012-2015$ \\
\hline Inspiring Pakistani Youth to Reach Excellence through Counseling and Training (INSPYRE) & $2009-2015$ \\
\hline Inspiring Leadership, Empowerment and Development (iLEAD) & $2011-$ \\
\hline Youth Empowering Spaces (YES) & \multicolumn{2}{|l}{} \\
\hline Government of Khyber Pakhtunkhwa & 2015 \\
\hline Monthly Stipend Scheme for Unemployed Youth & $2010-2013$ \\
\hline Free Provincial Youth Technical Education Scheme (PYTES) & 2016 \\
\hline Government of Balochistan & 2015 \\
\hline Free Laptop scheme (For 50,000 students) & \\
\hline Youth ICT Initiative (Oracle, Java, J2EE \& CISCO Certified Trainings) & \\
\hline
\end{tabular}

\section{Non-governmental Efforts}

Pakistan's youth bulge and its far-reaching implications for development necessitate augmentation of government efforts for youth from non-governmental quarters, in particular NGOs and donor agencies. With respect to the former, at present, it is difficult to assess the exact number of private organizations engaged in youth-related interventions since no central repository of data is available. Nor has any countrywide exercise been conducted to map organizations working for youth development, although the NGO Bargad did undertake a census of youth-related organizations in Islamabad and Punjab in 2011. This identified 62 organizations in Islamabad and 372 youth organizations working in Punjab.

For the purposes of this study, we attempted to obtain a rough idea of the number of local and international organizations working on youth issues through an extensive Internet search and by contacting known organizations. According to the data collected, only a limited number of organizations are currently engaged in youth-related programs and research, and very few of them have a nationwide focus and coverage. These organizations are mainly working in Sindh and Punjab, with the remaining small number thinly distributed across KP, Balochistan, Azad Jammu and Kashmir (AJK), and Gilgit-Baltistan (GB).

In its census of NGOs in Punjab, Bargad (2011) found that organizations working formally or informally on youth issues comprised as little as 5 percent of those registered with the Social Welfare Department, implying a ratio of one NGO for every 66,000 youth. This seems to indicate that youth are a less important focus among NGOs, although comparison with proportions focusing on other issues would be required for a firmer conclusion. Bargad's survey had found that most youth organizations do not focus on rural areas or on marginalized and out of school youth. Our inquiry too found that NGO efforts, while geographically scattered, were mainly located in urban areas. As the previous chapter has shown, rural youth are at higher risk of skewing of life trajectories so their relative neglect in NGO efforts is a concern.

Bargad (2011) had found the main priority in NGOs' youth interventions to be education programs, with a neglect of marriage issues and business potentials through training and microcredit. However, we found most NGOs working with youth to have a focus on skill development, employment, and also general and sexual health, in addition to education. Possibly, over the past five years, the scope of youth programs in the non-governmental sector has 
widened beyond the undoubtedly vital realm of education. NGOs are also working to promote later marriages, girls' empowerment, family and life skills, social security networks, sports, and political empowerment, but these are much smaller in number.

While updated data about donor investment in youth is lacking, a 2014 report of the United Nations entitled Pakistan: Donor Profile and Mapping is helpful in obtaining an idea of recent activity. According to the report, twelve major international donor agencies were contributing to development in Pakistan in 2014. All of them supported youth-related interventions, eight as a primary focus, and the remaining four as a program sub-component. The key initiatives and relevant details are summarized in Table 4.4. Donor agencies are working with a range of implementing partners, including public sector departments, as well as private national and international organizations. The most heavily focused area of investment is education, followed by skill development; health and human rights are also a focus. Generally, these investments were made under countrywide programs, although special attention has been accorded to unprivileged or neglected areas of KP and the adjoining, conflict-ridden Federally Administered Tribal Areas (FATA). On the other hand, very few organizations were reported to be investing in Balochistan, and only USAID had a focus on the province. According to the timeline given in Table 4.4, about half of the above-mentioned agencies are currently working in Pakistan and their investment plans vary, the longest stretching to 2020.

The foregoing brief overview indicates that there is willingness among governmental as well as nongovernmental stakeholders to focus on youth. While priority areas vary, the efforts collectively amount to a fairly broad spectrum of interventions for meeting young people's health, educational, economic, and empowerment needs. However, the picture may be less balanced when we focus on specific regions or compare urban and rural areas. Moreover, while the range of efforts may be encouraging, their scale, in comparison to the target population, may not be so. More data and further research are required to assess where we really stand in terms of meeting the needs of young people.

31 
Table 4.4: Thematic Focus of Youth-related Donor Investments in Pakistan

Donor-funded Programs with a Focus on Youth

\begin{tabular}{|c|c|c|c|c|}
\hline Agency & Youth-related area of funding & Project date & Geographic focus & Implementing partners \\
\hline $\begin{array}{l}\text { Australian Agency for } \\
\text { International Development } \\
\text { (AUSAID) }\end{array}$ & $\begin{array}{l}\text { Education (36\%) and health } \\
(26 \%)\end{array}$ & 2011-2015 & $\begin{array}{l}\text { Nation-wide, specifically under- } \\
\text { privileged and remote areas }\end{array}$ & $\begin{array}{l}\text { Government organizations, multilateral } \\
\text { development organizations }\end{array}$ \\
\hline $\begin{array}{l}\text { Global Affairs } \\
\text { Canada/Department of } \\
\text { Foreign Affairs, Trade and } \\
\text { Development (DFATD) }\end{array}$ & $\begin{array}{l}\text { Protecting children and youth } \\
\text { (education and sustainable } \\
\text { economic growth with focus } \\
\text { on female empowerment) }\end{array}$ & 2011-2017 & Nation-wide & $\begin{array}{l}\text { Government organizations, multilateral } \\
\text { development organizations, donors, NGOs, } \\
\text { academia, media, volunteers and the private } \\
\text { sector. }\end{array}$ \\
\hline European Union (EU) & Formal and vocational training & 2007-2013 & $\begin{array}{l}\text { Countrywide - disaster-affected } \\
\text { areas }\end{array}$ & $\begin{array}{l}\text { Democracy Reporting International, World Bank, } \\
\text { UNDP, Inter news, International Alert, Search for } \\
\text { Common Ground, Community Appraisal and } \\
\text { Motivation Programme Society - CAMP, PAIMAN } \\
\text { Alumni Trust, International Foundation for } \\
\text { Electoral Systems, Trust for Democratic Education } \\
\text { and Accountability (TDEA) / Free and Fair Elections } \\
\text { Network }\end{array}$ \\
\hline Government of Norway & $\begin{array}{l}\text { Education, gender equality and } \\
\text { human rights }\end{array}$ & $\begin{array}{l}\text { Funded till } \\
2014\end{array}$ & $\begin{array}{l}\text { Nation-wide specifically } \\
\text { neglected areas (KP and GB) }\end{array}$ & $\begin{array}{l}\text { National and local level development partners, the } \\
\text { Unities nations (UN) system, e.g., United Nations } \\
\text { office on Drugs and Crime (UNODC), United } \\
\text { Nations office for the Coordination of } \\
\text { Humanitarian Affairs (OCHA), National Disaster } \\
\text { Management Authority (NDMA), and NGOs. }\end{array}$ \\
\hline
\end{tabular}


Donor-funded Programs with a Focus on Youth

\begin{tabular}{|c|c|c|c|c|}
\hline Agency & Youth-related area of funding & Project date & Geographic focus & Implementing partners \\
\hline Government of Germany & $\begin{array}{l}\text { Health }(19 \%) \text { and } \\
\text { education/vocational training } \\
(4 \%)\end{array}$ & $2015-2020$ & $\begin{array}{l}\text { Countrywide, with a focus on KP } \\
\text { and FATA }\end{array}$ & $\begin{array}{l}\text { Dept. of Education in KP, Islamabad, Azad Jammu } \\
\text { and Kashmir (AJK), Balochistan, Punjab, Federally } \\
\text { Administered Tribal Areas (FATA); National } \\
\text { Vocational and Technical Training Commission } \\
\text { (NAVTTC), Technical Education and Vocational } \\
\text { Training Authority (TEVTA) in all provinces and } \\
\text { regions. Health: Dept. of Health in KP, AJK, Gilgit } \\
\text { Baltistan (GB) and FATA; National Planning } \\
\text { Commission and national Ministry for Health; } \\
\text { social security stakeholders, including Benazir } \\
\text { Income Support Programme (BISP); civil society } \\
\text { organizations. }\end{array}$ \\
\hline $\begin{array}{l}\text { Swiss Development and } \\
\text { Cooperation (SDC) }\end{array}$ & $\begin{array}{l}\text { Promotion of human rights } \\
\text { and education of women and } \\
\text { girls }\end{array}$ & $\begin{array}{l}\text { 2012-2014; } \\
\text { extended to } \\
2016\end{array}$ & $\begin{array}{l}\text { Countrywide, with focus on KP, } \\
\text { FATA and Northern Areas }\end{array}$ & $\begin{array}{l}\text { Local and national NGOs and public institutions; } \\
\text { United Nations Development Program (UNDP), } \\
\text { United Nations Children's Fund (UNICEF), } \\
\text { International Labour Organization (ILO and } \\
\text { International Union for Conservation of Nature } \\
\text { (IUCN); international financial institutions, e.g., } \\
\text { World Bank, ADB; governments of KP and Pakistan; } \\
\text { State Bank of Pakistan; commercial banks and } \\
\text { leasing companies; donors focusing on } \\
\text { microfinance }\end{array}$ \\
\hline $\begin{array}{l}\text { UK Department for } \\
\text { International Development } \\
\text { (DFID) }\end{array}$ & $\begin{array}{l}\text { Education (31\%) (sectoral } \\
\text { reforms) }\end{array}$ & 2011-2019 & Nation-wide & $\begin{array}{l}\text { Government entities at national, provincial/ } \\
\text { regional and district levels, private sector, } \\
\text { academia, media and local civil, society } \\
\text { organizations in programme implementation, and } \\
\text { strategic partnership with the World Bank }\end{array}$ \\
\hline $\begin{array}{l}\text { Government of the } \\
\text { Netherlands* }\end{array}$ & Education (50\%) & $\begin{array}{l}\text { Funded till } \\
2015\end{array}$ & Malakand Division of KP & $\begin{array}{l}\text { UNICEF, Save the Children, World Vision and GIZ; } \\
\text { provincial and district education government } \\
\text { officials }\end{array}$ \\
\hline
\end{tabular}


Donor-funded Programs with a Youth Component

\begin{tabular}{|c|c|c|c|c|}
\hline Agency & Youth-related area of funding & Project date & Geographic focus & Implementing partners \\
\hline $\begin{array}{l}\text { US Agency for International } \\
\text { Development (USAID) }\end{array}$ & $\begin{array}{l}\text { Education (8\%) and health } \\
(6 \%)\end{array}$ & $\begin{array}{l}\text { Funding till } \\
2019\end{array}$ & $\begin{array}{l}\text { Countrywide, especially } \\
\text { underrepresented geographical } \\
\text { areas, like Balochistan, Northern } \\
\text { Areas, GB and AJK }\end{array}$ & $\begin{array}{l}\text { Government organizations, NGOs, private sector } \\
\text { (55 implementers) }\end{array}$ \\
\hline Asian Development Bank & $\begin{array}{l}\text { Education }(2 \%) \text { and health } \\
(3 \%)\end{array}$ & $2013-2019$ & Countrywide & $\begin{array}{l}\text { Government, State Bank of Pakistan, Khushali Bank } \\
\text { of KP, and NGOs involved in micro financing }\end{array}$ \\
\hline $\begin{array}{l}\text { Japan International } \\
\text { Cooperation Agency (JICA) }\end{array}$ & $\begin{array}{l}\text { Capacity development of } \\
\text { technical and vocational } \\
\text { institutes, non-formal } \\
\text { education }\end{array}$ & $\begin{array}{l}\text { Funded till } \\
2014\end{array}$ & KP and Punjab & Provincial education departments \\
\hline The World Bank & $\begin{array}{l}\text { Education and skill } \\
\text { development }\end{array}$ & & Countrywide, including FATA & $\begin{array}{l}\text { Federal ministries, autonomous bodies, } \\
\text { provincial/regional departments throughout the } \\
\text { country, local civil society organizations, private } \\
\text { sector }\end{array}$ \\
\hline
\end{tabular}

Source: Extracted from United Nations, Pakistan: Donor Profile and Mapping, 2014.

* In addition to the initiatives identified in the UN's donor mapping, the Royal Danish Embassy is also supporting the "Youth Parliament of Pakistan," which was created in 2007 and is playing an important role in engaging Pakistani youth in a healthy political discourse and in exposing them to the democratic process and practices. 


\section{NEXT STEPS}

In conclusion, much more is required to enable and equip the next generation to lead Pakistan's development into the next decade. The discourse about the routes of youth empowerment and engagement appears to be very nascent given the time to invest is now, when we have the largest cohorts of young people at the cusp of adulthood. Some possible ways of grappling with the intricacy and multiplicity of issues are presented here.

It is clear from the evidence presented in the paper that there is a need to work together across sectors, agencies, and universities. The government, private sector, NGOs, and development partners need better coordination to pool efforts to secure positive pathways for Pakistan's upcoming generation. The current scenario of standalone policies with little or no integration and poor linkages across sectors does not provide the framework for such coordination. The paper touches on the wide territory across which we must carefully chart a course, negotiating the challenges of child protection against early marriages and child labor; education reforms, particularly to enforce compulsory education at least until the secondary level and also to introduce programs for out of school children; provision of reproductive health services and rights information; promotion of civic participation; development of leadership and political rights awareness; and the most important area of skills building, job creation and economic opportunities.

As in other countries, a Task Force on the demographic dividend with a limited time assignment may be required to develop the intersectoral thinking required to launch scaled-up initiatives and a discourse between sectors, public and private in particular. Oversight for the launch of such initiatives could also rest with this Task Force, which could start as a national entity followed by the setting up of similar forums in the provinces. Once identified, the broad areas and initiatives could be taken up for funding by government, private sector and international partners. This will ensure the amplification of efforts rather than the scattered distribution of resources presently seen.

After the 18th Amendment, it goes without saying that each province must take into account its own specific situation and address its priorities. Given the nature and interconnectedness of the interventions required to fully tap the potential of young persons, the policy home should probably be in the development/growth policy of each of the provinces.

The most important lesson that the paper presents is the argument for a differentiated approach when developing and implementing policies with a youth focus. The three or more age cohorts that comprise young people are in the midst of radically different life transitions in this fluid and formative period of their life, and there is strong evidence presented here (and more can be culled from national and international data sources) that priority needs vary depending on how broadly youth are classified and which specific cohort is focused. Therefore the responses to youth issues have to be carefully stratified and would require a specific set of sectors and agencies to be assigned to take responsibility.

Even more importantly youth have to be differentiated by gender, residential and most critically economic class differences across each of the provinces. Life is totally different for young persons across rich and poor households in terms of avenues of information, resources to avail opportunities, and the options that they can tap. Therefore a monolithic program for young people, even if it is restricted to a province or a particular geographical area, is from the beginning misplaced. Efforts have to be targeted where they most count and are likely to have the greatest impact-among the most vulnerable groups.

It is clear that living in and moving to urban areas, young people are likely to have greater opportunities than those living in rural areas not only in terms of education and employment, but also in the form of reduced gender inequities. There is no doubt that young girls living in poor rural households are the worst off by any measure of vulnerability, 
as they face a triple whammy of poverty, discrimination, and marginalization. They are definitely the group to whom the maximum attention and resources should be directed.

As reflected in our initial review of programs, many organizations also focus their work in urban areas. The exception may be large-scale programs with a rural focus, such as the Benazir Income Support Program, Lady Health Worker program and the Rural Support Programmes Network (RSPN), which do extend their work in rural areas. At the moment, these have an indirect impact on adolescent lives but their work could be diversified to include initiatives especially tailored to target youth with wider rural and poorer household impacts.

In view of the scale and complexity of Pakistan's youth challenge and the need for urgency, it is essential that government and non-governmental stakeholders work together, dovetailing their specific contributions within a shared and clearly articulated framework of priorities and action, and ensuring that the most is made of limited resources by avoiding overlap and maximizing synergy. The lack of easily available data on government, donor and NGO efforts on youth is a telling sign that coordination in this sector must improve substantially if we are to collectively invest where and when young people most need our support. 


\section{REFERENCES}

Ahmad, R., \& Azim, P. (2010). Youth Population and the Labour Market of Pakistan: A Micro Level Study. Pakistan Economic and Social Review, 48(2), 183-208.

Akhtar, S., \& Shahnaz, L. (2006). Understanding the Youth Unemployment Conundrum in Pakistan: A Macro-Micro Analysis. Indian Journal of Labour Economics, 49(2).

Bargad. (2011). Youth Directory 2011. Vol. 1: Youth Mapping Study of Punjab and the Islamabad Capital Territory (ICT). Bargad - Organization for Youth Development. Gujranwala, Pakistan.

Bloom, D.E. (2013). In Z. A. Sathar, R. Royan, \& J. Bongaarts (eds). Capturing The Demographic Dividend In Pakistan (pp. vii-ix). Islamabad, Pakistan: Population Council.

Bongaarts, J., Sathar, Z. A., \& Mahmood, A. (2013). Population Trends in Pakistan. In Z. A. Sathar, R. Royan, \& J. Bongaarts (eds). Capturing The Demographic Dividend In Pakistan (pp. 13- 23). Islamabad, Pakistan: Population Council.

British Council. (2009). Pakistan: The Next Generation. British Council, Islamabad.

British Council. (2013). Next Generation Goes to the Ballot Box. British Council, Islamabad.

Faizunissa, A., \& Haque, M. U. (2003). Adolescent Reproductive Health: The Role of Agency and Autonomy. The Pakistan Development Review, 42(4), 569-583.

Faizunissa, A., \& Ikram, A. (2004). Determinants of Youth Development in Pakistan. The Lahore Journal of Economics, 9(2), 119-133.

Government of Balochistan. (2014). Proposed Balochistan Development Vision and Strategy-Concept Note. (Draft). Chief Minister's Policy Reform Unity. Government of Balochistan.

Government of Balochistan. (2015). Balochistan Youth Policy 2015, (Draft). Environment, Sports and Youth Affairs Department. Government of Balochistan.

Government of Balochistan. (2015). Population Policy of Balochistan 2015-2025. (Draft). Population Welfare Department. Government of Balochistan.

Government of Khyber Pakhtunkhwa. (2010). Khyber Pakhtunkhwa Health Sector Strategy 2010 - 2017. Government of Khyber Pakhtunkhwa.

Government of Khyber Pakhtunkhwa. (2012). Minimum Health Services Delivery Package for Primary Health Care Facilities in Khyber Pakhtunkhwa. Department of Health. Government of Khyber Pakhtunkhwa.

Government of Khyber Pakhtunkhwa. (2014). Integrated Development Strategy 2014-2018. Government of Khyber Pakhtunkhwa.

Government of Khyber Pakhtunkhwa. (2015). Population Policy - Khyber Pakhtunkhwa. Population Welfare Department. Government of Khyber Pakhtunkhwa.

Government of Khyber Pakhtunkhwa. (2016). Khyber Pakhtunkhwa Youth Policy. Sports, Tourism, Culture, Archeology, Museum and Youth Affairs Department. Government of Khyber Pakhtunkhwa.

Government of Pakistan. (2008). Pakistan Employment Trends: Youth 2008. Labour Market Information and Analysis Unit, Ministry of Labour, Manpower and Overseas Pakistanis, Series 3, Islamabad. 
Government of Pakistan. (2010). Labour Policy 2010. Ministry for Labour and Manpower. Government of Pakistan. Available at http://www.eobi.gov.pk/announcement/labour+poilcy+2010.pdf.

Government of Pakistan. (2010). Youth Strategy: Issues, Challenges and Opportunities. Policy Brief on Youth, Planning Commission Ministry of Planning, Development and Reform. Government of Pakistan. Islamabad. Available at http://www.pc.gov.pk/feg/PDFs/youth.pdf.

Government of Pakistan. (2013). Pakistan 2025 One Nation-One Vision. Planning Commission, Ministry of Planning, Development and Reform. Government of Pakistan. Islamabad.

Government of Punjab. (2008). Minimum Services Delivery Standards for Primary and Secondary Health Care in Punjab. Pakistan Devolved Social Services Programme. Government of Punjab.

Government of Punjab. (2012). Health Sector Strategy. Government of Punjab.

Government of Punjab. (2012). Punjab Youth Policy 2012. Youth Affairs, Sports, Archeology and Tourism Department. Government of Punjab.

Government of Punjab. (2013). Adolescent Strategy and Strategic Plan 2013-17. Youth Affairs, Sports, Archeology and Tourism Department. Government of Punjab.

Government of Punjab (2015). Punjab Growth Strategy (2018). Accelerating Economic Growth and Improving Social Outcomes. Planning and Development Department. Government of Punjab.

Government of Punjab. (2015). Punjab Child Marriages Restraint Act 2015. (Amendment Bill) Provincial Assembly of Punjab. Available at http://pcsw.punjab.gov.pk/child_marriage.

Government of Punjab. (2016). Population Policy 2016 - Punjab. (Draft). Population Welfare Department. Government of Punjab.

Government of Punjab. (2016). The Punjab Restriction on Employment of Children Ordinance 2016. Law and Parliamentary Affairs Department. Available at http://www.dgpr.punjab.gov.pk/vd/dgpr/media/doc/ Punjab\%20Child\%20Labour\%200rdinance\%202016.pdf.

Government of Sindh. (2007). Sindh Strategy for Sustainable Development. Planning and Development Department. Government of Sindh.

Government of Sindh (2012). Health Sector Strategy: Sindh 2012-2020. Government of Sindh.

Government of Sindh. (2013). The Sindh Child Marriages Restraint Act 2013. Provincial Assembly of Sindh. Available at http://rtepakistan.org/wp-content/uploads/2014/11/The-Sindh-Child-Marriages-RestraintAct-2013.pdf.

Government of Sindh. (2015). Population Policy 2015. Improving the Quality of Life of Women and Children, (Draft). Population Welfare Department. Government of Sindh.

Government of Sindh. (2016). Sindh Youth Policy, (Draft). Sports and Youth Affairs Department. Government of Sindh.

Hamid, S., Johansson, E., \& Rubenson, B. (2010). Security Lies in Obedience-Voices of Young Women of a Slum in Pakistan. BMC Public Health, 10:164.

Hamid, S., Stephenson, R., \& Rubenson, B. (2011). Marriage Decision-making, Spousal Communication and Reproductive Health among Married Youth in Pakistan. Global Health Action, 4(5079), 1-8.

Hennink, M., Rana, l., \& Iqbal, R. (2005). Knowledge of Personal and Sexual Development amongst Young People in Pakistan. Culture, Health \& Sexuality, 7(4), 319-332. 
Hou, X. (2010). Challenges for Youth Employment in Pakistan: Are They Youth-Specific? The Pakistan Development Review, 49(3), 193-212.

Hussain, A. (2013). Meeting the Challenge of Demographic Change through Equitable Development. In Z. A. Sathar, R. Royan, \& J. Bongaarts (eds.), Capturing the Demographic Dividend in Pakistan (pp. 69-79). Islamabad, Pakistan: Population Council.

International Labour Organization (ILO). (2014). Strengthening Labour Migration Governance in Pakistan. International Labour Organization. Pakistan, Islamabad.

Jinnah Institute. (2013). Apolitical or Depoliticised? Pakistan's Youth and Politics: A Historical Analysis of Youth Participation in Pakistan Politics. Jinnah Institute. Pakistan.

Khawar, S. (2011). Full Circle - Pakistan: The Next Generation Report and the Perspective of Pakistani Youth. In M. Kugelman and R. M. Hathaway (eds.), Reaping the Dividend: Overcoming Pakistan's Demographic Challenges (pp. 106-120). Woodrow Wilson International Center for Scholars.

Kugelman M., and Hathaway R. M. (2011). Reaping The Dividend Overcoming Pakistan's Demographic Challenges. Woodrow Wilson International Center for Scholars, Washington, D.C.

Lloyd, C.B., and Grant, M.J. (2005). Growing Up in Pakistan: The Separate Experiences of Males and Females. In C. B. Lloyd, J. R. Behrman, N. P. Stromquist, and B. Cohen, The Changing Transitions to Adulthood in Developing Countries: Selected Studies (pp. 320-366). Panel on Transitions to Adulthood in Developing Countries. Committee on Population. Division of Behavioral and Social Sciences and Education. Washington, DC: The National Academies Press.

Lloyd, C. B., Mete, C., and Grant, M.J. (2007). Rural Girls in Pakistan: Constraints of Policy and Culture. In M. Lewis and M. Lockheed (eds.), Exclusion, Gender and Schooling: Case Studies from the Developing World (pp. 99-118). Washington, D.C: Center for Global Development.

McCarthy, K., Brady, M., and Hallman, K. (2016). Investing When It Counts: Reviewing the Evidence and Charting a Course of Research and Action for Very Young Adolescents. Population Council. New York.

Mete C. and Jamil R. R. (2013). Enhancing Labor Market Conditions for Vulnerable Groups. Pakistan Policy Note 7. The World Bank. South Asia Region.

Mir, A. M., Wajid, A., Pearson, S., Khan, M., \& Masood, I. (2013). Exploring Urban Male Non-marital Sexual Behaviours in Pakistan. Reproductive Health, 10(22), 8.

National Institute of Population Studies (NIPS) [Pakistan] and ICF International. (2013). Pakistan Demographic and Health Survey (PDHS) 2012-13. Islamabad, Pakistan, and Calverton, Maryland, USA: NIPS and ICF International.

Pakistan Bureau of Statistics (PBS). (2006). Labour Force Survey 2005-06. Government of Pakistan. Statistics Division Pakistan Bureau of Statistics, Islamabad.

Pakistan Bureau of Statistics (PBS). (2015). Labour Force Survey 2014-2015. Government of Pakistan. Statistics Division Pakistan Bureau of Statistics, Islamabad.

Pakistan Bureau of Statistics (PBS). (2015). Pakistan Social and Living Standards Measurement (PSLM) Survey (2014-15). Government of Pakistan, Statistics Division, Pakistan Bureau of Statistics, Islamabad.

Population Council. (2016). Landscape Analysis of Family Planning in Pakistan. Report submitted to Bill and Malinda Gates Foundation. Population Council. Islamabad. 
Qayyum, W. (2007). Causes of Youth Unemployment in Pakistan. The Pakistan Development Review 46: 4 Part II (Winter), 611-621.

Robalino, D., \& Cho, Y. (2012). Labor Market Policies under a Youth Bulge: How to Benefit from Demographic Dividend in Pakistan. World Bank Policy Paper Series on Pakistan, PK 14/12.

Sabir, I., \& Zaman, M. (2013). Youth Violence in Pakistan: The Social Structure and Culture of Violence. Profilaktyka Społeczna i Resocjalizacja, (21), 7-24.

Sathar, Z. A., \& Royan. R. (2013). In Z. A. Sathar, R. Royan, \& J. Bongaarts (eds). Capturing The Demographic Dividend In Pakistan (pp. 101- 107). Islamabad, Pakistan: Population Council.

Sathar, Z. A., Royan, R., \& Bongaarts, J. (eds) (2013). Capturing The Demographic Dividend In Pakistan. Islamabad, Pakistan: Population Council.

Sathar, Z. A., Lloyd, C. B., Haque, M. U., Diers, J. A., Faizunissa, A., Grant, M., \& Sultana, M. (2003). Adolescents and Youth in Pakistan 2001-2002: A Nationally Representative Survey. Islamabad: Population Council.

Sustainable Development Policy Institute. (2013). Youth Voters Statistics. Sustainable Development Policy Institute. Islamabad. Available at http://elections.sdpi.org/youth/Youth_voter_statistics.

The Commonwealth. (2013). Youth Development Index (YDI), Results Report. Available at http://www.youthdevelopmentindex.org/cms/cms-youth/_images/197918019952385f3219c75.pdf.

United Nations Development Programme (UNDP). (2016). Fast Facts: Youth as Partners for the Implementation of the SDGs. Bureau for Policy and Program Support, UNDP.

United Nations Pakistan. (2014). Pakistan Donor Profile and Mapping 2014. United Nations Pakistan. Available at http://www.un.org.pk/wp-content/uploads/2014/04/Pakistan-Donor-Profile-and-Mapping-by-UN.pdf.

United Nations. (2015). Transforming Our World: The 2030 Agenda for Sustainable Development. Available at http://www.un.org/pga/wp- content/uploads/sites/3/2015/08/120815_outcome-document-of-Summitfor-adoption-of-the-post-2015-development-agenda.pdf.

World Population Foundation. (2009). Revised Country Strategy Paper-Pakistan 2009-2012. World Population Foundation. Islamabad. 